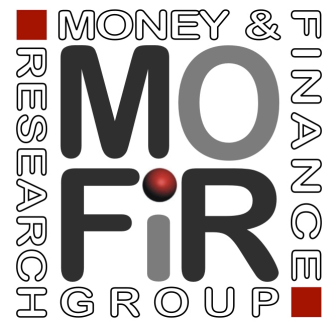

THE FADING STOCK MARKET RESPONSE TO ANNOUNCEMENTS OF BANK BAILOUTS

Francesco Marchionne Michele Fratianni

Working paper no. 76

January 2013 
January 18,2013

\title{
The fading stock market response to announcements of bank bailouts
}

\author{
Michele Fratianni \\ Kelley School of Business \\ Indiana University \\ Bloomington, IN 47405 \\ fratiann@indiana.edu \\ and \\ Università Politecnica delle Marche \\ Piazzale Martelli, 8 \\ 60121 Ancona, Marche \\ Italy \\ and \\ Money and Finance Research Group (MoFiR) \\ Piazzale Martelli, 8 \\ Ancona, Marche 60121 \\ Italy \\ m.fratianni@univpm.it
}

Francesco Marchionne

Nottingham Trent University

Division of Economics

Burton Street, NG1 4BU

Nottingham

United Kingdom

and

Money and Finance Research Group (MoFiR)

Piazzale Martelli, 8

Ancona, Marche 60121

Italy

francesco.marchionne@ntu.ac.uk

\section{Acknowledgement}

We thank Matteo Cassiani for providing us with bank data. We are grateful to two referees and the editor of the journal for constructive comments and suggestions. 


\section{Highlights}

The fading stock market response to announcements of bank bailouts

- Paper analyzes government announcements of recue plans for banks in the recent crisis

- Traditional methods show announcements were priced by markets as abnormal returns

- But these effects disappear with modern estimation methods

- Conclusion: either announcements not credible or plans inadequate relative to problem 
This draft: January 8, 2013

\title{
The fading stock market response to announcements of bank bailouts
}

\author{
by \\ Michele Fratianni* and Francesco Marchionne**
}

\begin{abstract}
$\underline{\text { Abstract }}$
We analyze the effects on bank valuation of government policies aimed at shoring up banks' financial conditions during the 2008-2009 financial crisis. Governments injected into troubled institutions massive amounts of fresh capital and/or guaranteed bank assets and liabilities. We employ event study methodology to estimate the impact of government-intervention announcements on bank valuation. Using traditional approaches, announcements directed at the banking system as a whole were associated with positive cumulative abnormal returns, whereas announcements directed at specific banks with negative ones. Findings are consistent with the hypothesis that individual institutions were reluctant to seek public assistance. However, when we correct standard errors for bank-and-time effects, virtually all announcement impacts vanish in Europe, whereas they weaken in the United States. The policy implication is that the large public commitments were either not credible or deemed inadequate relative to the underlying financial difficulties of banks.
\end{abstract}

JEL Classification: G01, G21, N20

Keywords: announcement, bank, event study, financial crisis, rescue plan.

* Indiana University, Kelley School of Business, Bloomington, IN 47405, Università Politecnica delle Marche, Department of Economics, 60121 Ancona (Italy), and Money and Finance Research Group (MoFiR), e-mail: fratiann@indiana.edu.

** corresponding author, Nottingham Trent University, Division of Economics, NG1 4BU Nottingham (United Kingdom), and and Money and Finance Research Group (MoFiR), 60123 Ancona (Italy); e-mail: francesco.marchionne@ntu.ac.uk. 


\section{The fading stock market response to announcements of bank bailouts}

\section{INTRODUCTION}

The financial tsunami of the 2007-2009 crisis produced massive expenditure commitments on the part of governments aimed at shoring up their national banking systems. Governments intervened massively and repeatedly to support banks during the crisis. At first, governments reacted to the sharp declines in equity prices with disjointed and ad-hoc interventions. The failure of Lehman on September 15, 2008 was a watershed and prompted policymakers in the next two months to implement programs addressing systemic problems, such as the $\$ 700$ billion Troubled Asset Relief Program (TARP) in the United States and the $£ 500$ billion banking recapitalization program in the United Kingdom. The initial objective of purchasing sub-standard illiquid assets ran into difficulties because, without a market, governments were likely to either overvalue "toxic" assets, thus penalizing taxpayers, or undervaluing them, thus penalizing potential sellers. Governments then adjusted their policy by either recapitalizing financially distressed banks (e.g., in the United States) or nationalizing them (e.g., in the United Kingdom). In December 2008 and January 2009, governments tried to douse the fire of the crisis by targeting specific large banks (e.g., Commerzbank and Citigroup); they were unsuccessful. In February and March 2009, additional general measures were taken, this time with a focus to relieve banks of bad assets. At the same time, many indebted US banks began repaying the US government, while in Europe the number of banks that had signaled their intention for government assistance declined (Wilson and $\mathrm{Wu}, 2012$ ).

In this paper, we examine the impact of these interventions by measuring the market's reaction to their announcements. Hence, we take the viewpoint of bank shareholders. To do so, we create an original dataset that distinguishes government announcements directed at the banking system as a whole (general announcements) from those directed at specific banks (specific 
announcements) in the spirit of the distinction made by Carvalho et al. (2010). Then, we apply event-study methodology to estimate the impact of government interventions on bank valuation. The maintained hypothesis is that the announcement of a rescue plan is credible if it affects rates of return of the targeted banks. We test for these effects by computing cumulative abnormal returns (CAR) and abnormal risks of the participating banks around a window that includes announcement dates.

We perform three separate tests on our sample of large banks. The first estimates the overall impact on banks' equity value of the two types of rescue announcements; the second estimates whether bank size impacts on announcement effects; and the third considers announcements of different types. Our traditional parametric approach shows that general and specific announcements were priced by the markets as CAR and abnormal risks over the selected time windows. In particular, general announcements were associated with positive CAR and decreasing abnormal risks, whereas specific announcements were associated with negative CAR and increasing abnormal risks. However, when we apply more modern techniques to control for auto-correlation and crosscorrelation dependence -that is, correcting for both bank and time effects- announcement coefficients lose statistical significance. This reversal is robust to different estimators, traditional as well as modern, and is not driven by sample selection, the length of the event window, or multiple announcements. The findings are consistent either with announcements being not credible or related to rescue programs of inadequate size relative to the underlying problem.

The paper is organized as follows. Section 2 reviews the relevant literature. Section 3 examines event-study methodology and describes our testable equations. Data are presented in Section 4. Sections 5 and 6 employ, respectively, traditional and recent event-study methodology to estimate the impact of government interventions on bank valuation. Section 7 presents findings using a mixed estimation method. Section 8 tests the robustness of results. Conclusions are drawn in the last section. 


\section{RECENT LITERATURE}

The recent event-study literature shows that announcements by governments or international institutions tend to have weak or mixed effects on bank valuation. During the Asian crisis of 1997, IMF program announcements increased bank shareholder wealth only marginally, with the exception of South Korea (Kho and Stulz, 2000); East Asian government announcements of debt guarantees, instead, exerted a stronger positive impact on bank stock prices. Klingebiel et al. (2001) argue that these announcements, however, were not credible because the same announcements exerted a negative impact on stock prices of non-financial firms.

Papers on the 2008-2009 financial crisis also conclude with mixed results. Several studies focus on the US TARP. Veronesi and Zingales (2010) examine the first component of TARP known as the Paulson Plan, consisting of $\$ 125$ billion of capital infusion in the nine largest US commercial and investment banks. These authors find that the targeted banks received a net benefit estimated at $\$ 130$ billion, with the bulk of the gain going to bondholders. Taxpayers, who received preferred shares in exchange for the capital infusion, suffered a loss estimated between $\$ 21$ and $\$ 44$ billion. Veronesi and Zingales apply, among other methods, a difference-in-difference event study approach in which each (treated) bank in their sample is compared with the largest non-bank (nontreated) financial company so as to isolate the effect of the Paulson Plan from other events'. Bayazitova and Shivdasani (2012) analyze incentives of US banks to participate in the Capital Purchase Program and the Capital Assistance Program of TARP. Under the former, banks' participation neither conveyed a certification motivation nor sent an adverse signal to the market. Banks' stock prices were unaffected by participation announcements because infusions took the form of preferred non-dilutive stock. Under the latter, instead, capital infusion took the form of common equity and included stress tests that conveyed a significant certification effect. The authors employ a large sample of 590 publicly traded US banks and use sequential logit to estimate 
participation incentives in the two programs and a standard event study to evaluate the impact of participation announcements. Elyasiani et al. (2011) investigate investors' reactions to the announcements of private equity offerings and TARP capital injections using an event study methodology. Investors react negatively to private equity offerings, whereas the opposite takes place with respect to TARP capital injections. Black and Hazelwood (2012) examine the impact of TARP capital injections on risk-taking by targeted banks and find heterogeneity between large and small TARP banks. Finally, Huerta et al. (2011) find that the TARP program reduced short-run volatility of the US stock market.

There are fewer country studies outside of the United States. For example, GoldsmithPinkham and Yorulmazer (2009) look at the Northern-Rock episode in UK. Their event study shows a negative spillover effect of the bank-run event and a strong positive effect of the government bailout announcement on the rest of the UK banking system. Xiao (2009) applies the Veronesi and Zingales's (2010) methodology to French government announcements in 2008. The French plan reduced banks' credit risk and financing costs but had a mixed impact on equity: the gross impact measured by raw stock returns was positive but economically small, whereas the adjusted impact, measured by CAPM abnormal returns, was statistically significant but economically very negative.

Panel studies reveal even more ambiguous effects than country studies. Panetta et al. (2009:2) find that government interventions were effective in reducing banks' default risk, albeit “banks' equities showed [only] a slightly positive reaction.” These outcomes could be explained by a variety of factors, such as capital injections dilute investors' earning and voting rights, governments become so involved with banks to reduce investors' perception of their long-run profitability, or that a non-credible exit strategy might raise the uncertainty on the duration of public interventions. Klomp (2010) considers the effectiveness of government announcements on CDS premia using a multilevel quantile regressions and finds that "the effect of government interventions 
is heterogeneous across the risk distribution of a bank" (p. 20). King (2009), employing country-bycountry time series, uncovers that the announcement impact is heterogeneous across countries, with positive effects on US banks and negative ones on European banks. An interesting paper by Carvalho et al. (2010) studies how the subprime financial crisis affected the lending relationship between borrowers and banks during the first phase of the financial crisis encompassing the collapse of Bear Sterns and Lehman Brother. These authors use a relatively large sample of publicly traded firms located in 34 countries and distinguish events producing "diverse effects [...] among banks" (p. 3) in response to announcements of asset write-downs of individual banks. The salient finding of the paper is that during the period in question the financial shock was transmitted from banks to relationship borrowers. The study also finds a positive and statistically significant link between the relationship borrower's stock return and the return of its main bank that reported an asset a write-down over a week event window.

Our paper differs from the previous literature in four ways. First, our sample of large banks covers 19 countries and, hence, permits a much richer experience than the US TARP, other individual countries, and previous panel studies. Second, we examine a longer crisis period, starting from the date of the Lehman failure to the end of 2009 that includes multiple announcements. Third, we employ an even-study parameter as opposed to standard event study: this methodology is more flexible in hypothesis testing and in controlling for bank and time effects. Fourth, we subject the hypothesis to a long battery of tests aimed at ascertaining the robustness of our results. Finally, we distinguish between general and specific announcements and between announcements of capital injections and those of asset and debt guarantees.

\section{EMPIRICAL MODEL}

3.1 Methodology 
The rescue of several large financial institutions in the United States and in Europe was sparked by the migration of liquidity risk from banks to other financial institutions and followed the rapidly expanding role of government as a market maker of last resort to support, not only big banking, but also big finance. We employ event-study methodology to estimate markets' reaction to the announcements of government interventions.

Event-study methodology goes back to the 1930s (Dolley, 1933), but became ubiquitous in capital markets research after important contributions by Ball and Brown (1968) and Fama et al. (1969). The spreading popularity of this technique, however, was accompanied by modifications of the original setup that implied violations of the underlying statistical assumptions (MacKinlay, 1997). Corrections and practical adjustments to these practices surfaced in the second half of 1970s (Serra, 2002; Corrado, 2009). There is now agreement that the general setup of this methodology consists of three stages: the identification of an event of interest and its timing; the specification of a valuation model; and an analysis and computation of CAR around the event date (De Jong, 2007:2). The procedure can be implemented in two alternative ways (Binder, 1998). The first is a two-step approach, in which a valuation model is first estimated over a control (pre-event) estimation period and then CAR is computed as cumulative residuals of the valuation model over an event window (O'Hara and Shaw, 1990). The second is an event-parameter approach, in which the valuation model is estimated over the combined estimation and event periods, and includes dummy variables over a relevant event window (Meulbroek, 1992).

The two approaches are unbiased and equivalent under the assumption of serially independent and normally distributed returns and non-overlapping event windows (Corrado, 2009). Conversely, problems arise in the presence of overlapping windows, multiple events, aggregation of abnormal returns across firms, cross-sectional dependence, serial correlation, event-induced volatility and event-induced returns (Pynnönen, 2005; De Jong, 2007). A number of these statistical problems can be overcome with the regression framework (Binder, 1998). In our case, general 
announcements are clearly overlapping because they influence all banks in a country; furthermore, if different countries were to coordinate their policies, overlapping would be exacerbated. Also, public interventions become multiple events when the same bank receives subsidies repeatedly during the crisis. In the presence of overlapping multiple events, Binder (1998) suggests the use of event-parameter methodology because it allows more simple and efficient estimates, it is more flexible in hypothesis testing, and it avoids aggregation problems and information losses connected with the two-step approach.

\subsection{Testable Equations}

We propose three separate tests using the event-parameter methodology. The first aims at uncovering the overall impact on banks' equity value of general and specific announcements; the second at identifying too-big-to-fail or too-big-to-save policies; and the last test breaks down announcements by different types. In the first test, daily rates of returns on bank stock $i$ of country $j$ at time $t, R_{i j t}$, are regressed on an intercept, capturing the risk-free rate of return, on the market rate of return, $R^{M}{ }_{j}$, and two dummy-event variables. The first, $G_{j t}$, is equal to one during the event time window, $T$, around a general announcement; otherwise it is zero. The second, $S_{i t}$, is equal to one in the time window $T$ around a specific announcement. These dummy variables capture the average shift over the event period on the intercept, i.e., the normal return. We interact also $G_{j t}$ and $S_{i t}$ with $R_{i j t}$ to check for changes in risk-taking over the event period. The test is formalized as follows:

$$
R_{i j t}=\alpha+\beta \cdot R_{j t}^{M}+\gamma \cdot G_{j t}+\lambda \cdot R_{j t}^{M} \cdot G_{j t}+\delta \cdot S_{i t}+\rho \cdot R_{j t}^{M} \cdot S_{j t}+Z_{i t}+u_{i j t},
$$

where $Z$ indicates bank size and $u$ denotes a well-behaved residual. In terms of returns, markets' reactions to announcements are captured by $\gamma$ and $\delta$ : returns in the time window $T$ are predicted to be different than returns in other periods; that is, the government-intervention event generates CAR. Since the error of the regression must be zero on average, the null hypothesis is that CAR, within $T$, must also be zero. A rejection of the null hypothesis corroborates the presence of abnormal returns. In (1), CAR are the sum of the estimates of parameters $\gamma$ and $\delta$ multiplied by $T$ (Meulbroek, 1992). 
In terms of risks, instead, the impact of general and specific announcements is measured respectively by $\lambda$ and $\rho$. Both effects depend on market perception. General announcements are met by a positive market's reactions, both in terms of returns $(\gamma>0)$ and market risk $(\lambda<0)$, if they provide a credible safety net for the entire banking system. Specific announcements, instead, affect negatively equity valuation $(\delta<0)$ and market risk $(\rho>0)$ because they provide the "news" that the targeted bank is financially distressed (King, 2009:24; Aït-Sahalia et al., 2010:4).

The second test checks for announcement effects varying with bank size. Due to their key role in the national financial system, the largest banks are considered by governments too big to fail. The implication is that public interventions could benefit disproportionally them against other banks (O'Hara and Shaw, 1990). Black and Hazelwood (2012), who analyze the effects of TARP, find an increase in risk-taking by large banks that received capital injections relative to non-TARP banks, whereas the opposite holds for small TARP banks relative to non-TARP banks. But, if resources allocated to rescue plans are insufficient, the largest banks could become too big to save and the effect of a public intervention becomes negative. Demirguc-Kunt and Huizinga (2010) find empirical evidence that is consistent with too-big-to-save banks. We test the too-big-to-fail and toobig-to-save hypotheses by interacting bank size $Z$ with general and specific announcements:

$$
R_{i j t}=\alpha+\beta \cdot R_{j t}^{M}+\gamma \cdot G_{j t}+\lambda \cdot R_{j t}^{M} \cdot G_{j t}+\eta \cdot Z_{i t} \cdot G_{j t}+\delta \cdot S_{i t}+\rho \cdot R_{j t}^{M} \cdot S_{j t}+\mu \cdot Z_{i t} \cdot S_{i t}+Z_{i t}+u_{i j t} \cdot
$$

Significantly positive (negative) estimates of $\eta$ and $\mu$ are consistent with a too-big-to-fail (too-bigto-save) policy.

The third test breaks down $G$ and $S$ by different intervention types. The formulation of the test is given by equation (3):

$$
R_{i j t}=\alpha+\beta \cdot R_{j t}^{M}+\sum_{k=C A P, G U A}\left(\gamma_{k} \cdot G_{j k t}+\lambda_{k} \cdot R_{j t}^{M} \cdot G_{j k t}+\delta_{k} \cdot S_{i k t}+\rho_{k} \cdot R_{j t}^{M} \cdot S_{j k t}\right)+Z_{i t}+u_{i j t}
$$

The only difference with respect to equation (1) is that announcement coefficients are now denoted with a subscript $k$ to indicate their type. We distinguish between capital injection $(C A P)$ and asset- 
and-debt guarantees $(G U A)$. In (3), CAR for the $k$-type announcement is equal to the estimate of $\gamma_{k}$ and $\delta_{k}$ times $T$. We expect abnormal returns of general and specific announcement for different types of interventions to be similar to those of equation (1). Effects on market risk will vary according to the intervention type. Capital injections increase market risk because of the higher degree of moral hazard consequent to the revelation of a soft government budget constraint. With asset-and-debt-guarantees, governments commit a future and uncertain financial expenditure should a negative event occur. This commitment is conditional on certain constraints and requirements imposed on banks. Under competition for limited resources, distressed banks feel they must meet requirements as a necessary condition to qualify for these guarantees. If this discipline effect dominates the moral hazard effect, market risk declines; if the conditions are reversed, market risk rises.

\section{DATA}

Our data set consists of daily rates of return (inclusive of dividends) of 19 national market indices and of 122 banks listed within these indices over the period from July 31, 2007 to December 31, 2009. ${ }^{1}$ The listed banks are shown in Table A1 of the Appendix; Bloomberg is the source of the data. July 31, 2007 is the starting point, a pre-crisis date. September 15, 2008, the day when Lehman Brothers filed for Chapter 11 bankruptcy protection, is widely acknowledged as a watershed of the crisis. March 9, 2009, the day when the US equity market bottomed out, represents another turning point in the crisis. From July 31, 2007 to March 9, 2009, \$3.34 trillion of market valuation was destroyed in our bank sample (Fratianni and Marchionne, 2009). European and US banks were hit the hardest, with a 80 and 76 percent respective declines; Pacific banks fared better with a 52 percent decline. Furthermore, the valuation was about twice as large after September 15, 2008 than in the first phase of the crisis.

\footnotetext{
${ }^{1}$ Banks' capitalization reached its top on July 31, 2007, whereas by December 31, 2009 most government interventions had already been in place.
} 
We also collected announcement dates of government rescue plans over the same period. As mentioned, we classify general and specific announcements (Tables A2 and A3, respectively, in the Appendix). We used a variety of sources: BNP Paribas (2009), DLA Piper (online), International Capital Market Association (online), Mediobanca (2009), Panetta et al. (2009), and websites of CNN Money and national Ministries of Finance or Treasuries. For the 19 countries represented in our sample, there are 51 general announcements over 33 different dates, of which 30 are capital injections and 21 are asset-and-debt guarantees (Table A2). There are 137 specific announcements over 88 different dates, of which 102 are capital injections and 35 asset-and-debt guarantees (Table A3). Specific announcements affect 52 of the 122 banks and two thirds of the countries in our sample. ${ }^{2}$ Table 1 presents frequencies of government announcements by country. The difference between the number of general announcements and the number of countries indicates the presence of multiple general announcements: 11 of the capital-injection type and two of the asset-and-debtguarantee type. The number of multiple specific announcements, instead, is equal to the difference between the number of specific announcements and the number of targeted banks: 50 of the capitalinjection type and 17 of the asset-and-debt-guarantee type. Despite the fact 33 banks were the target of multiple announcements, these announcements were concentrated in few banks: for example, 12 for Hypo Real Estate, five for Bank of America and SNS Reaal, and four for Citigroup and ING Groep.

From the date of Lehman's failure to the end of 2009, governments committed $\$ 8.6$ trillion in general rescue packages, of which 37.6 percent as capital injections and 63.4 percent as assetand-debt guarantees (Table A2). Differences in the committed amounts cannot be explained only by differences in size of national financial markets. Table A3 reports commitments of specific interventions: they amount to $\$ 2.4$ trillion, of which 39.9 percent as capital injections and 60.1 percent as asset-and-debt guarantees. Considering all subsidies, the Royal Bank of Scotland and

\footnotetext{
${ }^{2}$ These countries are Austria, Belgium, France, Greece, Germany, Ireland, Italy, Luxembourg, Netherlands, Portugal, Sweden, the United Kingdom, and the United States.
} 
Lloyds TBS top the list followed by Citigroup, Hypo Real Estate, Dexia and Bank of America. All announcements occurred after the Lehman's failure, except for the support given to JP Morgan Chase \& Co. to save Bear Stearns of March 14, 2008.

In sum, governments used a mix of general and specific interventions. Asset-and-debt guarantees are politically attractive because governments do not have to argue the case with legislators. They also entail little or no cash outlay and are a natural instrument when governments want to gamble for a possible resurrection of the banking system. This strategy was a defining characteristic of both the US Savings and Loans crisis of the Eighties and the long Japanese crisis of the Nineties, which was responsible for transforming "a relatively small cost into a staggeringly large one" (Glauber, 2000:102).

Table 2 shows descriptive statistics for the pre-Lehman (PRE) and the post-Lehman (POST) failure periods. Bank returns $R_{i}$ tend to be procyclical in both periods. The variability of $R_{i}$ (measured by its standard deviation) is higher than the variability of market returns, $R_{m}$, and rises from PRE to POST. Both individual $\left(S I Z E_{i}\right)$ and overall $\left(S I Z E_{m}\right)$ market capitalizations of banks decrease around 35 percent from $P R E$ to $P O S T$, implying no material changes in relative bank size (SIZEREL). The within serial variability of $S I Z E_{i}$ falls from 45 to 36 between the two periods, whereas the overall variability of $S I Z E_{m}$ rises from 444 to 738 , implying an increase in the between cross-sectional variability. The main message is that the financial crisis enlarged size differences among banks.

[Insert Tables 1 and 2, here]

The hypothesis underlying our analysis is that the announcement of a rescue plan is credible if it raises the rates of return of participating banks. Therefore, we can test the effects of rescue plans by computing CAR and abnormal risks of participating banks around an announcement-date window. Alpha, the risk-free rate, and beta, the market risk parameter, from the capital asset price model are estimated on daily returns. A general announcement is more complex than a specific 
announcement because it requires longer time for the market to process it; in addition, it is easier for the markets to obtain relevant information about general than specific announcements. For this reason, we apply different windows to the two types of announcements: a seven-day window for general announcements centered on the announcement date, and a five-day window for specific announcements centered on the announcement date. We exclude UK banks from the estimation because UK capital injections were in fact nationalizations that tend to be unfavorable to private shareholders and can distort market reactions resulting, for example, from the reduction of traded volumes and the provision of an explicit safety net. The omission of the United Kingdom from the sample eliminates Northern Rock, a pre-Lehman bailout case. ${ }^{3}$ Since the number of pre-crisis bailouts would have included only Bear Stearns-JP Morgan, in the empirical work that follows we focus on the post-Lehman period.

To compare different estimators, we create a balanced panel by dropping CIT Group Inc., which filed Chapter 11 on November 2, 2009, and by eliminating days corresponding to a national holiday. Finally, we concentrate on the post-Lehman period. In light of the fact that $P R E$ has zero general announcements and one specific announcement, the base model is estimated over the $P R E$ period for comparison purposes. Summing up, our final panel consists of 115 banks and 329 working days spanning from September 15, 2008 to December 31, 2009.

\section{TRADITIONAL APPROACH}

\subsection{Findings using dummies}

The first test estimates the overall impact of 48 general and 130 specific announcements on banks' returns using the entire panel of 115 banks. We test equation (1) by aggregating all announcements $(A L L)$. We recall that $G$ and $S$ have seven-day and five-day windows respectively. We experimented with different window lengths (see Section 8). We have added a relative bank size measured by the

\footnotetext{
${ }^{3}$ Fannie Mae and Freddie Mac are excluded because they are not banks.
} 
US dollar capitalization value of bank $i$ relative to capitalization of all banks (SIZEREL). This variable turns out to have positive and statistically significant effects in nearly every regression.

Table 3 reports estimates of the model using different specifications with dummy variables. The first column reports the estimate in the pre-crisis period with the specification of column five. ${ }^{4}$ The difference between PRE and POST beta is statistically significant, but economically small, corroborating the view that the failure of Lehman Brothers, although a critical event, does not represent a structural break for the capital asset pricing model. Hence, we rely on this model to draw inference from announcements and focus on POST to exploit the greater variability in the data. This approach works against our null hypothesis of no significant announcement effects because announcement coefficients are expected to be more statistically significant in the presence of higher data variability.

The first key finding of Table 3 is that all announcements are statistically very significant and exert a substantive economic impact on banks' market returns. The second column of the table estimates equation (1) with Ordinary Least Squares (OLS). G-induced CAR are almost 4.3 percentage points higher than normal returns, while $S$-induced CAR are 1.9 percentage points lower than normal returns. ${ }^{5}$ The opposite signs of the $G$ and $S$ coefficients reflect differences in the way markets evaluate the two types of announcements. A general announcement is taken as a signal that government wants to protect the banking systems: the banking industry, as a whole, receives support and shareholders gain "abnormally" high rates of return over the announcement window. On the other hand, a specific announcement reveals previously unknown troubles. This pattern is corroborated also by the negative (positive) abnormal market risk for general (specific) announcements. ${ }^{6}$ Results appear consistent with the observed reluctance of individual institutions to

\footnotetext{
${ }^{4}$ Results from specifications of column two through four are very similar. In principle, bailout announcements should be evaluated using bankruptcy as the benchmark. Not knowing a true benchmark crisis, we resort to the alternative of estimating a pre-crisis period from July 31, 2007 to September 14, 2008.

${ }_{6}^{5} \mathrm{CAR}$ are obtained by multiplying $G$ and $S$ coefficients by the days of the event windows, respectively 7 and 5 .

${ }^{6}$ Our estimated betas are relatively high but much lower than those by Veronesi and Zingales (2010:348).
} 
ask for public assistance. The fear of being identified as a "bad apple" was also the reason why some banks were reticent to seek emergency lending from central banks.

Financial panel data are prone to two econometric problems. The first is that, in the presence of time-series dependence, the residuals of a given firm may be correlated across time periods and generate an unobserved firm effect (Wooldridge, 2007). For example, banks could differ in terms of firm characteristics such as leverage and portfolio risk. The second is that, in the presence of a cross-section dependence, the residuals may be correlated across different firms and generate an unobserved time effect. For example, to the extent that the credibility of a bailout announcement depends on the fiscal conditions of the country making the announcement, overlapping announcements in multiple countries are qualitatively different from those occurring in single countries; also market returns may not capture idiosyncratic effects of the whole banking sector, which may distort the CAPM alpha and beta. We control for these differences by introducing firm and time effects. In light of the fact that these effects violate the independence assumption underlying OLS, this procedure leads to biased and inconsistent estimates. Traditionally, the finance literature has corrected this bias with a parametric approach (Petersen, 2009). The third column of the table reports Least-Square-Dummy-Variables (LSDV) estimates using bank dummies to control for unobserved specific characteristics that may influence bank performance. Bank dummies capture, not only different bank characteristics, but also country effects by virtue of the fact that each bank is specific to a given country. It follows that bank effects already embody differences in bailout announcements across countries and control for any country fixed effects. The null hypothesis that there is no difference between the specifications of columns two and three cannot be rejected according to the Likelihood Ratio test. This is confirmed by the similar estimates of $G$ and $S$ and their interaction with the market rate of return obtained by OLS.

Column four of Table 3 includes time dummies that are correlated with general events as well as with multiple announcements. These dummies control for worldwide disturbances. 
Announcement effects weaken: $G$-induced CAR drop from 4.2 to 1.9 percent; $S$-induced CAR rise from -2.5 to -1.8 percent. Announcement impacts on abnormal risk strengthen: abnormal $G$ beta switch from -0.0582 to 0.108 and abnormal $S$ beta increases from 0.193 to 0.255 . The overall conclusion is that the data display also time-series dependence. Column five includes both bank and time dummies. The fact that the results of column five are closer to those of column four than to those of column three suggests that time effects dominate bank effects. Column five is the benchmark specification of Table 3 .

Two other important findings emerge from Table 3. The first is that there is evidence of neither too-big-to-fail nor of too-big-to-save policy, shown by statistically insignificant interaction terms of relative bank size with $G$ (column six). The second is that markets seem to sort out the relative efficacy of different announcement types. The impact on $R_{i}$ is driven by capital injection announcements (positive for $G^{C A P}$ and negative for $S^{C A P}$ ). The market risk parameter beta rises with $C A P$ for both types of announcements and $S^{G U A}$, but declines with $G^{G U A}$ (column seven). In sum, capital injection announcements are consistent with the benchmark result (but not with OLS), whereas asset-and-debt-guarantee announcements show statistically insignificant CAR and an inconsistent sign, relative to the benchmark equation, for betas.

\subsection{Robustness with Feasible Generalized Least Squares}

In financial studies, Feasible Generalized Least Squares (FGLS) are used to improve upon OLS and LSDV estimation (Maksimovic and Phillips, 2002; Gentry et al., 2003; Almazan et al., 2004). Yet, the literature points to at least three drawbacks when this technique is applied to event studies. The first is that estimating a high number of covariance parameters could "introduce even more inaccuracy into the standard errors than it eliminates" (Kolari and Pynnönen, 2010:3). In particular, FGLS tend to underestimate standard errors (SE) when the cross-sectional dimension increases (Beck and Katz, 1995). The second is that FGLS require an accurate estimation of the variancecovariance matrix, whereas the correct model specification is rarely known in event studies. The 
third is that a mis-specified model could lead to inefficient test results also with a known variancecovariance matrix (Chandra and Balachandran, 1990).

Table 4 shows FGLS estimates of our three equations. ${ }^{7}$ In column three we allow for bankspecific SE to follow an AR(1) process. The salient findings are that $G$-induced and $S$-induced CAR and beta are virtually the same as those of OLS (column two). When we specify a heteroskedastic error structure with cross-correlation, the intensity of announcement coefficients declines and the abnormal $G$ beta remains negative (column four). ${ }^{8}$ After rejecting the hypothesis of serial and crosssectional independence, we re-estimate equation (1) with an auto-correlated and cross-correlated error structure and find weaker announcement effects (column five). ${ }^{9}$ Column five is the benchmark specification of Table 4. Columns six and seven estimate equations (2) and (3): the results are not materially different from those obtained with LSDV even if some coefficients are statistically more significant than those under LSDV because SE are underestimated in large cross-sectional dimension of the sample (Beck and Katz, 1995). In sum, FGLS estimates corroborate the findings obtained with the dummy methodology, with a couple of exceptions.

$$
\text { [Insert Tables } 3 \text { and 4, here] }
$$

\section{RECENT APPROACHES}

\section{$\underline{6.1 \text { Findings with clustered standard errors }}$}

The parametric dummy approach assumes that bank and time effects are time-invariant and common to all banks (Wooldridge, 2007). In the presence of relevant omitted variables, the independence assumption of classic linear regression is violated because the error term becomes

\footnotetext{
${ }^{7}$ Column one reports estimate over the pre-crisis period using the benchmark specification of column five.

${ }^{8}$ Using time dummies, abnormal $G$ beta is positive (column four of Table 3 ).

${ }^{9}$ The serial correlation test, indicated by A-Corr in Table 3, is by Wooldridge and the cross-correlation test, indicated by X-Corr, is by Wald.
} 
correlated with the regressors. ${ }^{10}$ In addition, the OLS estimator performs poorly because its SE over or underestimate the true variability of the coefficient estimates. ${ }^{11}$ LSDV standard errors understate the true SE when independent variables and residuals are correlated across observations within the same bank or the same time period, even though independence is maintained in the other dimension (Petersen, 2009). In this case, the magnitude of the error rises with the number of time periods for a firm effect and with the number of banks for a time effect. A further problem with the parametric approach is that it imposes a fixed dependence structure. If, on the contrary, time-series dependence is temporary (Petersen, 2009) or cross-section dependence varies across banks (Wooldridge, 2007), LSDV over-reject the null hypothesis of the coefficients being not significantly different from zero.

To avoid this overconfidence bias, we apply a cluster correction to SE, a method specifically designed to control for correlated residuals (Rogers, 1993). Clustered SE do not assume any parametric structure and become more efficient as the number of clusters grows (Donald and Lang, 2007). But, cluster correction works only for one dimension. A common approach to deal with two dimensions involves using dummies for one dimension and clustered SE for the other (Petersen, 2009). The solution works, however, only if the dependence structure is correctly specified. In the meantime, the technology has evolved: Cameron et al. (2006) and Thompson (2006) have succeeded in giving us a clustering procedure working simultaneously on two dimensions. To sum up, in the presence of both bank and time effects, SE clustered on only one dimension are biased downward. The magnitude of this bias varies with the number of clusters. With a sufficient number of clusters in each dimension, "standard errors clustered on multiple dimensions are unbiased and produce correctly sized confidence intervals" with both fixed or temporary firm effects and common or non-constant time effects (Petersen, 2009:475-76).

\footnotetext{
${ }^{10}$ The direction of the bias depends on the estimated coefficients as well as the covariance between the regressors and the omitted variables. Given a positive estimated coefficient, a positive covariance will lead the OLS estimator to overestimate the true value of the coefficient.

${ }^{11}$ In particular, greater number of periods and firms, larger bias in OLS standard errors.
} 
Treating our equations with clustered SE yields surprising results (Table 5). With time dummies and clustering by banks, $G$ coefficients maintain the same sign, intensity and statistical significance, but coefficients of abnormal $S$ beta tend to lose some statistical significance (column three). With bank dummies and clustering by days, the impact of both $G$ and $S$ on $R_{i}$ vanishes (column four). Under double clustering by banks and days, not only the effects of announcements disappear (except, marginally, for $S^{A L L}$ ), but the impact of relative bank size becomes half the size of the regression with time clustered SE (column five). Column five is the benchmark model of Table 5. In sum, once one controls for bank and time effects parametrically, announcement effects tend to fade away.

Differences are substantial also for equations (2) and (3). In contrast to LSDV and FGLS estimates, we find evidence consistent with a too-big-to-save policy: the negative and strongly statistical significance of $S I Z E R E L * G^{A L L}$ coefficient in column six of Table 5 suggest that the benefits from general announcements are bigger for small than for large banks. A possible explanation is that, under the constraint of small budgets, a subsidy competition may occur among banks. ${ }^{12}$ Governments may gamble that it is better to save many small banks than one or two large banks. Finally, on the relative power of different intervention types, coefficients tend to be much less statistically significant than those of the corresponding specifications of Tables 3 and 4: $G$ induced CAR are statistically insignificant for both types of interventions, $S$-induced CAR are insignificant only for the asset-and-debt guarantee type, and three out of four abnormal betas are significant at least at the 10 percent level.

\subsection{Robustness with Fama-MacBeth and Driscoll-Kraay standard errors}

Cluster correction yields more accurate SE than those obtained with OLS. But, given that this procedure "places no restriction on the correlation structure of the residuals within a cluster, its

\footnotetext{
${ }^{12}$ On the relationship between protected (too-big-to-fail) banks and competitors, Hakenes and Schnabel (2010) show theoretically that an increase in the bail-out probability need not provoke a higher degree of risk-taking in the protected bank, but it does for its competitor. Hryckiewicz (2012), on the other hand, finds empirically that government interventions significantly raise risk in banking several years later.
} 
consistence depends on having a sufficient number of clusters" (Petersen, 2009:455). With a low number of clusters, clustered SE underestimate the true SE. ${ }^{13}$ Albeit our data sample consists of 115 banks and 329 working days, the large difference between the two dimension sizes could be still problematic for double clustering.

We check the robustness of the cluster correction results using two different methods. The first is by Fama and MacBeth (1973) who run a cross-sectional regression for each time period and use the time series of these estimates for the final estimates of the parameters and their SE. This procedure was originally designed to address a time effect: unbiased estimates are obtained averaging firm cross-section results of time-series regressions. The procedure can be also applied to firm effects, but not for both at the same time. The second method is by Driscoll and Kraay (1998) who estimate a variance-covariance matrix that is robust to general forms of cross-sectional and temporal dependence. Their method applies a Newey-West (1987) correction to the sequence of cross-sectional averages of the moment conditions and produces consistent SE independently of the number of clusters (Hoechle, 2007). In other words, the Driscoll-Kraay method overcomes the limitations, not only of FGLS (i.e., known dependence structure) and double clustering (i.e., requirement of many clusters), but also of the Fama-MacBeth method (i.e., only one correlation dimension).

The results obtained using Fama-MacBeth and Driscoll-Kraay SE are shown in Table $6 .{ }^{14}$ Under the standard Fama-MacBeth method, announcement coefficients are statistically insignificant (column four). When this method is applied to bank dimension, three out of four announcement coefficients are significant (column three). A comparison of columns three through five reveals that time effects (residuals correlated across different banks) dominate bank effects (residuals correlated through time). Under Driscoll-Kraay, announcement coefficients are statistically insignificant

\footnotetext{
${ }^{13}$ The bias declines fast as the number of clusters increases.

${ }^{14}$ Column two reproduces the benchmark specification of Table 4 (column five).
} 
except for $G$ (column five). Absent are too-big-to-fail or too-big-to-save policies (column six). About announcement types, CAR for general (specific) announcements are significantly positive (negative) only for capital injections, whereas abnormal beta is positive only for $G^{G U A}$.

In sum, empirical findings are sensitive to the method used to control for bank and time effects and change considerably as one moves from traditional to more recent approaches. The final message is that government announcements have exerted a very weak impact on bank returns. It follows that our evidence is more consistent with the hypothesis that state aid to banks acted more like an insurance than needed financial support. In this connection, the fact that all large US banks redeemed all the state aids in less than a year from disbursement (a big coordinated redemption wave taking place in June 2009) quickly corroborates the insurance view of government assistance.

[Insert Tables 5 and 6, here]

\section{MIXED APPROACH}

Bank and time dummies correct the bias of OLS coefficients; more recent approaches, instead, adjust their SE. ${ }^{15}$ Since both bank and time effects could have a fixed and a variable component, the natural step would be to avoid simultaneously both the omitted variable bias and residual correlation. We combine the two approaches into a mixed one. Table 7 shows results of this exercise for our three equations. All columns include bank and time dummies; for columns two through four we employ double-clustered SE, the most efficient method in the presence of many clusters, and for columns five through seven Driscoll-Kraay SE, a consistent method that is insensitive to the number of clusters. Petersen (2009) suggests a rule of thumb to select the best method. Clustered SE are best with more than 50 clusters for each of the two dimensions, whereas Driscoll-Kraay SE is best otherwise. We report both methods because results could also be affected by large differences between the number of firm clusters and time clusters.

\footnotetext{
${ }^{15}$ FGLS is an intermediate step in that it goes beyond the dummy approach but incompletely. Furthermore, FGLS cannot be used with clustered standard errors or Driscoll-Kraay standard errors at the same time.
} 
These two methods converge and are stabler than those of Tables 5 and 6 . The impact of government announcements on bank valuation is not statistically significant, with the exception of positive abnormal risks of specific announcements (columns two and five). There are three exceptions to this "fading star" effect. The first is the too-big-to-save effect for $G$ (columns three and six) that is consistent with that of Table $5 .{ }^{16}$ The second is the lower and less significant abnormal beta for $G^{G U A}$ (columns four and seven). The third is the negative CAR and positive abnormal risk of $S^{C A P}$ (columns four and seven). ${ }^{17}$ However, we stress that the null hypothesis of the joint significance of announcements is rejected in three out of six columns of Table 7 and is marginally significant in the other two columns. In sum, a careful treatment of bank and time effects stabilizes coefficient estimates and shows that government announcements of rescue plans have very weak effects on bank valuation.

[Insert Table 7 here]

\section{ROBUSTNESS}

We check the robustness of our findings with five separate exercises. The first estimates our three equations with bank-and-time dummies and double-clustered SE over a restricted subperiod. The second estimates the same three equations with bank-and-time dummies and Driscoll-Kraay SE for the entire period, but with two different bank subsamples. The reason for switching from double clustering to Driscoll-Kraay has to do with the higher efficiency of the latter when the number of clusters is low (Thompson, 2006; Petersen, 2009). The third and fourth test announcement effects, respectively, using different event windows and distinguishing first from successive announcements. The fifth transforms bank-specific rescue measures that took place simultaneously

\footnotetext{
${ }^{16}$ There is still a difference in statistical significance: column five has one star, whereas column two has three stars.

${ }^{17}$ The p-value of $R_{m} * S^{C A P}$ is exactly 5 percent.
} 
from October 28, 2008 through November 11, 2008 into a large implicit general rescue operation aimed at shoring up financial stability around the world.

On the first exercise, our selected subperiod is the most turbulent phase of the crisis, the one spanning from September 15, 2008 -the day of Lehman's failure- to March 6, 2009 -the bottom of the US market capitalization. It is in this phase that information asymmetry is deepest and governments make rescue announcements. Findings are shown in the first three columns of Table 8. The Wald test on announcements is statistically insignificant for equations (3) and significant at 10 percent level for equation (1). For equation (2), the statistical significance of the Wald test is due to the presence of SIZEREL $S^{A L L}$ rather than SIZEREL $G^{A L L}$ of Table 7. The unstable coefficient of SIZEREL interacting with announcements is not consistent with a too-big-to-fail policy.

On the second exercise, we rearrange our sample of countries in three large areas: the United States, Europe and the Pacific. The vast majority of announcements occurs in the first two areas, making the Pacific a poor candidate as a subsample. Given that the first area consists of only one country (the United States), we drop time dummies because they are perfectly collinear with market index $R^{M}$. To compare results, we adopt the same specification also for Europe. For both areas, we report estimates using Driscoll-Kraay SE because the number of firm clusters is lower than 50 (Table 8). Announcements coefficients are statistically significant for the United States (columns four through six) and insignificant in Europe (columns seven through nine). We find a different pattern with respect to the whole sample. In the United States, announcements affect only CAR whereas in Europe only $R_{m} * G^{A L L}$ has a significant coefficient. Both results corroborate the main hypothesis of positive $G$-induced effects and negative $S$-induced effects, but announcements impact weakly $R_{i}$ and differently across areas. Breaking down announcements by type, coefficients are statistically more significant and economically more relevant than those in Table 7 for the United States subsample, whereas they vanish in Europe. The only exception is the negative coefficient of $R_{m} * S^{C A P}$ (columns seven and eight). Two factors could drive these results beyond the absence of 
time dummies: the lack of policy coordination in Europe that undermines the credibility of government announcements, and the reputational benefit enjoyed by the United States as the financial leader of the world.

On the third exercise, we estimate our three equations applying alternatively two-day shorter and two-day longer windows than defined earlier (Table 9). ${ }^{18}$ Results for $G$ tend to weaken as the window is enlarged. For $S$, instead, the opposite holds. We explain this pattern by the fact that the $S$ evaluation process becomes more difficult as uncertainty rises with the deepening of the crisis. The overall message of the shorter and longer windows corroborates our earlier window selection.

[Insert Tables 8 and 9, here]

On the fourth exercise, we separate the effects of the first from successive announcements to verify whether government credibility evaporates with successive bailout announcements (Table 10). Three out of four F-tests reject the hypothesis of no difference between estimated announcement coefficients. In these cases, successive announcements have larger coefficients in absolute value than first announcements, implying that there is no credibility loss with multiple government announcements (column one). The pattern is similar when we apply traditional approaches to control for firm and time effects (columns two and three). Under Driscoll-Kraay or double clustered SE, the positive abnormal risk for first $S$ is the only statistically significant coefficient (columns four and five). The "fading effect" is sensitive to methodology, but it is independent of potential loss of credibility induced by multiple announcements.

Table 11 reports estimates of multiple announcements by type. Results confirm, on the whole, the findings of Table 10. In particular, larger (in absolute value) coefficient values of successive announcements than first announcements suggest that government credibility in committing resources to banks rises with multiple announcements. Negative CAR and abnormal risks of multiple $G$ are consistent with the government strategy to minimize its commitment and to

\footnotetext{
${ }^{18}$ We report estimates using double clustered SE, our best method in the presence of many firm and time clusters.
} 
gamble for bank resurrection. For $S$, first announcements signal government intentions (e.g., soft government budget constraint) and hidden information (e.g., troubled banks), which enhance the credibility that the same strategy will be continued in the future. The persistence of this government strategy tends to exacerbate moral hazard behavior on the part of banks. Overall, our results are in line with the recent literature that finds weak or no impact of subsequent bailout announcements on bank valuation. Klomp (2010) discovers that the effect of government interventions is only significant in the very short run. Similarly, Panetta et al. (2009) conclude that the announcements of comprehensive rescue packages do not seem to have a significant impact on banks' equity prices, which experience modest gains immediately after the announcements. Berndt et al. (2005) and King (2009) also find that banks' stock prices resume their pre-announcement downward trend just a few days after the announcements.

\section{[Insert Tables 10 and 11, here]}

Our last exercise checks the robustness of our results using a different definition of $G$ and $S$. We assume that the bank-specific announcements that took place simultaneously from October 28, 2008 through November 11, 2008 in various countries were coordinated so as to be one big implicit general announcement aimed at shoring up international financial stability. For that purpose, we treat all $S$ announcements over this 15 -day window as a single $G$. Table 12 reports seven estimates of the benchmark specification using our different methodologies. New $G$ and $S$ coefficients have the same signs but, on average, lower intensity than the corresponding original coefficients. The Wald test of the joint statistical significance of all announcements with those $\mathrm{S}$ included in the 15-day window treated as a single $G$ does not change for the first three columns of Table 12 relative to the corresponding original estimates. The Wald test in the fourth column shows a relative deterioration of the joint statistical significance. The same test in columns five (the turbulent subperiod) and six (US only) also show a relevant deterioration in statistical significance, whereas that in column seven (Europe only) an improvement but still within the range of statistical 
significance. In sum, under the assumption that bank-specific announcements from October 28, 2008 through November 11, 2008 were coordinated internationally, Table 12 accentuates the fading effects of bailouts on bank valuation.

The overall conclusion of our robustness exercises is that the "fading effect" of the announcements that emerges from our empirical work is robust to different periods, geographical subsamples, and event windows; furthermore, the fading effect is not driven by the existence of multiple announcements or alternative definition.

[Insert Table 12, here]

\section{CONCLUSIONS}

The great financial crisis of 2007-2009 prompted governments to inject vast sums of public funds into banks. Our paper has focused on the specific question of whether general and bank-specific announcements of government rescue plans were priced by the markets as cumulative abnormal returns and abnormal market risk during selected event-time windows. The paper also checks for the presence of too-big-to-fail and too-big-to-save policies. The headline result is that general and specific announcements were priced by the market as cumulative abnormal returns and abnormal market risk under standard estimation techniques, but these effects weakened or disappeared altogether when equations were subject to more rigorous tests.

The standard estimation techniques are parametric approaches, using either dummy variables or FGLS. With these methods, general announcements generate positive abnormal returns and lower market risk, whereas specific announcements generate negative abnormal returns and higher market risk, as in FGLS. The reason for the difference in sign between general and specific announcement is that when government intervenes to support an individual bank, the market perceives the subsidy as a revelation of partially unknown trouble and penalizes the bank identified as a "bad apple". 
The more rigorous estimation techniques address the important econometric issue of potential bank and time effects, that is the residuals of a given bank and/or day may be correlated across time periods and/or across different banks, respectively. When we correct for such effects, the coefficients associated with abnormal returns and market risk either lose statistical significance or manifest instability. This pattern of results is even clearer during the turbulent phase of the crisis and for European banks. US banks drive the findings, suggesting that the credibility of the announcements was sensitive to policy coordination. Europe had difficulty in coordinating their policies; in contrast, the United States had no coordination problem and also benefited from its role of the world's financial leader. We do not find evidence that the credibility of government announcements vanishes with multiple announcements. In sum, the overall conclusion is that announcement effects tend to fade away under closer econometric scrutiny.

Our results differ from findings obtained with different methodologies. For example, King (2009) finds, using event-study analysis, that announcements have the intended effects for US banks, but not for European banks. But, his methodology consists of applying country-by-country time series techniques that ignore cross-section dependence, a phenomenon that our paper has shown to generate large biases. In fact, we find that announcements impact more on risks than on returns. Moreover, our results are heterogeneous through different types of announcements.

The policy relevance of our findings is that government announcements of rescue plans were either not credible or deemed inadequate relative to the underlying financial difficulties of banks, particularly in Europe. It should be stressed that our analysis is limited to financial markets and to short-term reactions. Actual government interventions, as opposed to announcements of interventions, may exert positive effects on corporate borrowers' stock returns (Norden et al., 2012) or banks' loan supply (Li, 2012). Therefore, it is quite possible that, in the long run, one can arrive at an altogether different assessment of the effectiveness of rescue plans, but this is beyond the scope of our paper. Another issue needs to be highlighted: all our tests fail to show clear evidence 
of too-big-to-fail policy suggesting at most a too-big-to-save effect. Again, our short-term focus may be responsible for this result. To the extent that rescue plans lead to a consolidation of the banking system, the effects of too-big-to-fail or too-big-to-save policy may manifest themselves much later and in ways different from those analyzed in this paper.

\section{References}

Almazan, A., Brown, K., Carlson, M., Chapman, D. A., 2004. Why Constrain Your Mutual Fund Manager? Journal of Financial Economics, 73:289-321.

Ball, R., Brown, P., 1968. An Empirical Evaluation of Accounting Income Numbers, Journal of Accounting Research, 6(2):159-78.

Bayazitova, D., Shivdasani, A., 2012. Assessing TARP, Review of Financial Studies, 25:377-407.

Beck, N., Katz, J.N., 1995. What to do (and not to do) with time-series cross-section data, American Political Science Review, 89:634-647.

Berndt, A., Douglas, R., Duffie, D., Ferguson. M., and Schranz, D., 2005. Measuring default risk premia from default swap rates and EDFs, BIS Working Papers 173.

Binder, J.J., 1998. The event study methodology since 1969, Review of Quantitative Finance and Accounting, 11:111-137.

Black, L.K., Hazelwood, L.N., 2012. The effect of TARP on bank risk-taking, Journal of Financial Stability, forthcoming

BNP Paribas, 2009. To the rescue. Report of Market Economics, Interest Rate Strategy, Credit Strategy

Cameron, A.C., Gelbach, J.B., Miller, D.L., 2006. Robust inference with multi-way clustering. Working paper, University of California-Davis.

Carvalho, D, Ferreira, M., Matos, P., 2010. Lending relationships and the effect of bank distress: Evidence from the 2007-2008 financial crisis, Working paper, November.

Chandra, R., Balachandran, B.V., 1990. A synthesis of alternative testing procedures for event studies, Contemporary Accounting Research, 6:611-640.

CNN Money, online. http://money.cnn.com/news/specials/storysupplement/bankbailout/.

Corrado, C.J., 2009. Event Studies: A Methodology Review, available at SSRN: http://ssrn.com/abstract=1441581.

De Jong, F., 2007. Event Studies Methodology, Lecture Notes.

Demirguc-Kunt, A., Huizinga, H., 2010. Are banks too big to fail or too big to save? International evidence from equity prices and CDS spreads, CEPR Discussion Papers, 7903..

DLA Piper, online. http://www.dlapiper.com/it/austria/news/detail.aspx?news=2858.

Dolley, J.C., 1933. Characteristics and Procedure of Common Stock Split-Ups, Harvard Business Review, 11:316-26.

Donald, S., Lang, K., 2007. Inference with Difference in Differences and Other Panel Data, Review of Economics and Statistics, 89:221-33.

Driscoll, J., Kraay, A.C., 1998. Consistent covariance matrix estimation with spatially dependent data, Review of Economics and Statistics, 80:549-560.

Elyasiani, E., Mester, L., Pagano, M., 2011. Large Capital Infusions, Investor Reactions, and the Return and Risk Performance of Financial Institutions over the Business Cycle and Recent Financial Crisis, Working Paper, Federal Reserve Bank of Philadelphia. 
Fama, E., Fisher, L., Jensen, M., Roll, R., 1969. The adjustment of stock prices to new information, International Economic Review, 10:1-21.

Fama, E., MacBeth, J., 1973. Risk, Return and Equilibrium: Empirical Tests, Journal of Political Economy, 81:607-36.

Fratianni, M., Marchionne, F., 2009. The role of banks in the subprime financial crisis, Review of Economic Conditions in Italy, 2009/1:11-48.

Gentry, W., Kemsley, D., Mayer, C., 2003. Dividend Taxes and Share Prices: Evidence from Real Estate Investment Trusts, Journal of Finance, 58:261-82.

Glauber, R.R., 2000. Discussions of the Financial Crisis: Robert Glauber and Anil Kashyap, in Mikitani, R. and Posen, A.S. (eds.): Japan's financial crisis and its parallels to U.S. experience, Washington, DC: Institute for International Economics.

Goldsmith-Pinkham, P., Yorulmazer, T., 2009. Liquidity, bank runs, and bailouts. Spillover effects during the Northern Rock episode, Journal of Financial Services Research, 37(2-3):83-98.

Hakenes, H., Schnabel, I, 2010. Banks without parachutes: Competitive effects of government bailout policies, Journal of Financial Stability, 6: 156-168.

Hoechle, D., 2007. Robust standard errors for panel regressions with cross-sectional dependence, The STATA Journal, 7(3):281-312.

Huerta, D., Perez Liston, D., Jackson, D.O., 2011. The impact of TARP bailouts on stock market volatility and investor fear, Banking and Finance Review, 3(1)

Hryckiewicz, A., 2012. Government interventions - restoring or destroying financial stability in the long run?, Working Paper, June 1.

International Capital Market Association, online. http:/www.icmagroup.org/getdoc/d084024fe709-46e3-97a6-0b471 db7a7ea/Responses-to-market-turbulence--Countryplans.aspx\#Australia.

Kho, B.C., Stulz, R.M., 2000. Banks, the IMF, and the Asian Crisis, Pacific-Basin Finance Journal, 8:177-216.

King, M.R., 2009. Time to buy or just buying time. The market reaction to bank rescue packages, BIS Working Paper, n. 288.

Klingebiel, D., Krosner, R., Laeven, L.A., van Oijen, P., 2001. Stock Market Responses to Bank Restructuring Policies during the East Asian Crisis, World Bank Policy Research Working Paper Series, n. 2571, available at SSRN: http://ssrn.com/abstract $=632640$

Klomp, J., 2010. Government Interventions and Financial Soundness, CESifo Conference, Munich

Kolari, J.W., Pynnönen, S., 2010. Event Study Testing with Cross-Sectional Correlation of Abnormal Returns, Review of Financial Studies, 23(11):3996-4025

Li, L., 2012. TARP Funds Distribution and Bank Loan Growth, Working Paper, Boston College.

MacKinlay, A.C., 1997. Event Studies in Economics and Finance, Journal of Economic Literature, 35(1):13-39.

Maksimovic, V., Phillips, G., 2002. Do Conglomerate Firms Allocate Resources Inefficiently Across Industries? Theory and Evidence, Journal of Finance, 57:721-67.

Mediobanca, 2009. Sintesi dei principali piani di stabilizzazione finanziaria in Europe e negli Stati Uniti, Aggiornamento al 5 giugno 2009. Ricerche e Studi.

Meulbroek, L.K., 1992. An Empirical Analysis of Illegal Insider Trading, Journal of Finance, 47(5):1661-1699.

Newey, W. K., West, K.D., 1987. A simple, positive semi-definite, heteroskedasticity and autocorrelation consistent covariance matrix, Econometrica, 55:703-708.

Norden, L., Roosenboom, P., Wang, T., 2012. The Impact of Government Intervention in Banks on Corporate Borrowers' Stock Returns, EFA 2011 Meetings Paper.

O'Hara, M., Shaw, W., 1990. Deposit Insurance and Wealth Effects: The Value of Being "Too Big to Fail", Journal of Finance, 45(5):1587-1600. 
Panetta, F., Faeh, T., Grande, G., Ho, C., King, M., Levy, A., Signoretti, F.M., Taboga, M., Zaghini, A., 2009. An assessment of financial sector rescue programmes. BIS Paper, 48; http://www.bis.org/.

Petersen, M.A., 2009. Estimating Standard Errors in Finance Panel Data Sets, The Review of Financial Studies, 22(1):435-480.

Pynnönen, S., 2005. On regression based event study, in Erkki K. Laitinen and Teija Laitinen (eds.) Contributions to Accounting, Finance, and Management Science.Essays in Honor of Professor Timo Salmi. Acta Wasaensia, 143:327-354.

Rogers, W., 1993. Regression Standard Errors in Clustered Samples. Stata Technical Bulletin $13: 19-23$.

Serra, A.P., 2002. Event Study Tests: A Brief Survey. FEP Working Paper n.117.

Thompson, S., 2006. Simple Formulas for Standard Errors That Cluster by Both Firm and Time, Working paper, Harvard University.

Veronesi, P., Zingales, L., 2010. Paulson's Gift, Journal of Financial Economics, 97:339-368.

Wilson, L., Wu, Y.W., 2012. Escaping TARP, Journal of Financial Stability, 8:32- 42

Wooldridge, J., 2007. Econometric Analysis of Cross Section and Panel Data. Cambridge, MA: MIT Press.

Xiao, Y., 2009. French Banks Amid the Global Financial Crisis, IMF Working Paper, 09/201. 
Table 1: Number of government announcements and targeted banks, by country

\begin{tabular}{|c|c|c|c|c|c|c|c|c|c|c|}
\hline \multirow{3}{*}{ Area } & \multirow{3}{*}{ Country } & \multirow{3}{*}{$\begin{array}{l}\text { Total } \\
\text { Bank }\end{array}$} & \multicolumn{4}{|c|}{ General Announcements } & \multicolumn{4}{|c|}{ Specific Announcements } \\
\hline & & & \multicolumn{2}{|c|}{$C A P$} & \multicolumn{2}{|c|}{$G U A$} & \multicolumn{2}{|c|}{$C A P$} & \multicolumn{2}{|c|}{$G U A$} \\
\hline & & & $\begin{array}{c}\text { Total } \\
\text { Number }\end{array}$ & $\begin{array}{c}\text { Targeted } \\
\text { Banks }\end{array}$ & $\begin{array}{c}\text { Total } \\
\text { Number }\end{array}$ & $\begin{array}{c}\text { Targeted } \\
\text { Banks }\end{array}$ & $\begin{array}{c}\text { Total } \\
\text { Number }\end{array}$ & $\begin{array}{c}\text { Targeted } \\
\text { Banks }\end{array}$ & $\begin{array}{c}\text { Total } \\
\text { Number }\end{array}$ & $\begin{array}{c}\text { Targeted } \\
\text { Banks }\end{array}$ \\
\hline EUR & AT & 2 & 1 & 2 & 1 & 2 & 1 & 1 & 4 & 2 \\
\hline EUR & $\mathrm{BE}$ & 2 & 0 & 0 & 2 & 2 & 4 & 2 & 3 & 2 \\
\hline EUR & $\mathrm{CH}$ & 1 & 1 & 1 & 1 & 1 & 0 & 0 & 0 & 0 \\
\hline EUR & $\mathrm{DE}$ & 3 & 2 & 3 & 2 & 3 & 8 & 2 & 10 & 2 \\
\hline EUR & DK & 3 & 2 & 3 & 0 & 0 & 0 & 0 & 0 & 0 \\
\hline EUR & EI & 1 & 2 & 1 & 1 & 1 & 4 & 2 & 3 & 2 \\
\hline EUR & ES & 6 & 2 & 6 & 2 & 6 & 0 & 0 & 0 & 0 \\
\hline EUR & FR & 4 & 2 & 4 & 1 & 4 & 6 & 4 & 1 & 1 \\
\hline EUR & GR & 5 & 1 & 5 & 1 & 5 & 4 & 4 & 0 & 0 \\
\hline EUR & IT & 8 & 3 & 8 & 1 & 8 & 9 & 6 & 0 & 0 \\
\hline EUR & NL & 2 & 2 & 2 & 1 & 2 & 3 & 2 & 8 & 2 \\
\hline EUR & $\mathrm{NO}$ & 1 & 1 & 1 & 1 & 1 & 0 & 0 & 0 & 0 \\
\hline EUR & PT & 3 & 1 & 3 & 1 & 3 & 0 & 0 & 1 & 1 \\
\hline EUR & SE & 4 & 1 & 4 & 1 & 4 & 0 & 0 & 1 & 1 \\
\hline EUR & UK & 6 & 1 & 6 & 2 & 6 & 6 & 2 & 1 & 1 \\
\hline PAC & $\mathrm{AU}$ & 6 & 0 & 0 & 1 & 6 & 0 & 0 & 0 & 0 \\
\hline PAC & HK & 8 & 1 & 8 & 1 & 8 & 0 & 0 & 0 & 0 \\
\hline PAC & $\mathrm{JP}$ & 12 & 3 & 12 & 0 & 0 & 0 & 0 & 0 & 0 \\
\hline USA & US & 45 & 4 & 45 & 1 & 45 & 57 & 27 & 3 & 3 \\
\hline Total & & 122 & 30 & 114 & 21 & 107 & 102 & 52 & 35 & 17 \\
\hline
\end{tabular}

Note: Announcements: $C A P=$ Capital Injections; $G U A=$ Asset and Debt Guarantees. Area: EUR $=$ Europe; PAC $=$ Pacific region; USA $=$ United States. Country: $\mathrm{AT}=$ Austria; $\mathrm{BE}=\mathrm{Belgium} ; \mathrm{CH}=$ Switzerland; $\mathrm{DE}=\mathrm{Germany}$; $\mathrm{DK}=$ Denmark; $\mathrm{EI}=$ Eire; $\mathrm{ES}=$ Spain; $\mathrm{FR}=$ France; $\mathrm{GR}=$ Greece; IT=Italy; $\mathrm{NO}=$ Norway; $\mathrm{NL}=$ Netherlands; $\mathrm{PT}=$ Portugal; $\mathrm{SE}=$ Sweden; UK=United Kingdom; $\mathrm{AU}=$ Australia; HK=Hong-Kong; JP=Japan; US=United States. For general announcements, Targeted Banks is equal to Total Banks except for those countries that did not announce public interventions in favor of their banking system as a whole (e.g., Japan for GUA): the difference between Total Number and the number of countries (19) is equal to the number of multiple general announcements (when Total Number is larger than one). For specific announcements, Total Number is the number of government announcements aimed at supporting specific banks whereas Targeted Banks indicates not only how many banks are targeted by the government support, but also the number of first interventions in favor of targeted specific banks: the difference between Total Number and Targeted Banks is equal to the number of multiple specific announcements. Multiple specific announcements tend to be concentrated in few banks (not reported). 
Table 2: Descriptive statistics

Pre-Lehman failure period (31/07/2007-14/09/2008): 33,610 obs.

\begin{tabular}{lrr|rrrrr}
\hline Variable & \multicolumn{1}{c}{ Mean } & \multicolumn{1}{c}{ S.D. } & Minimum & \multicolumn{1}{c}{ Q1 } & \multicolumn{1}{c}{ Median } & \multicolumn{1}{c}{ Q3 } & Maximum \\
\hline$R_{i}$ & $-0.09 \%$ & $3.04 \%$ & $-58.67 \%$ & $-1.71 \%$ & $-0.11 \%$ & $1.34 \%$ & $40.85 \%$ \\
$R_{m}$ & $-0.07 \%$ & $1.51 \%$ & $-8.65 \%$ & $-0.95 \%$ & $0.00 \%$ & $0.76 \%$ & $10.72 \%$ \\
SIZE $_{i}$ & 33,287 & 45,319 & 956 & 7,055 & 15,353 & 40,459 & 320,147 \\
SIZE & $4,235,453$ & 444,594 & $2,610,880$ & $3,901,534$ & $4,246,899$ & $4,594,350$ & $5,132,827$ \\
SIZEREL & $0.79 \%$ & $1.07 \%$ & $0.02 \%$ & $0.17 \%$ & $0.37 \%$ & $0.98 \%$ & $8.38 \%$ \\
\hline
\end{tabular}

Post-Lehman failure period (15/09/2008-31/12/2009): 38,760 obs.

\begin{tabular}{lrr|rrrrr}
\hline Variable & \multicolumn{1}{c}{ Mean } & \multicolumn{1}{c}{ S.D. } & Minimum & \multicolumn{1}{c}{ Q1 } & \multicolumn{1}{c}{ Median } & \multicolumn{1}{c}{ Q3 } & Maximum \\
\hline$R_{i}$ & $0.03 \%$ & $5.36 \%$ & $-75.15 \%$ & $-2.20 \%$ & $0.00 \%$ & $2.03 \%$ & $86.98 \%$ \\
$R_{m}$ & $0.00 \%$ & $2.46 \%$ & $-13.03 \%$ & $-1.11 \%$ & $0.04 \%$ & $1.15 \%$ & $14.35 \%$ \\
$S_{I Z E_{i}}$ & 21,802 & 36,192 & 98 & 3,780 & 7,463 & 22,183 & 302,481 \\
$S_{I Z E_{m}}$ & $2,791,859$ & 738,404 & $1,314,889$ & $2,188,021$ & $2,694,310$ & $3,551,743$ & $3,950,598$ \\
SIZEREL & $0.78 \%$ & $1.25 \%$ & $0.00 \%$ & $0.15 \%$ & $0.28 \%$ & $0.86 \%$ & $9.83 \%$ \\
\hline
\end{tabular}

LEGEND

\begin{tabular}{lll}
\hline \multicolumn{1}{c}{ Name } & \multicolumn{1}{c}{ Formula } & \multicolumn{1}{c}{ Description } \\
$R_{i}$ & $=\frac{P X_{i, t}-P X_{i, t-1}}{P X_{i, t-1}}$ & $\begin{array}{l}\text { Daily rate of return of bank } i \text { ( } P X=\text { stock price in local } \\
\text { current units })\end{array}$ \\
$R_{m}$ & $=\frac{P X_{m, t}-P X_{m, t-1}}{P X_{m, t-1}}$ & $\begin{array}{l}\text { Daily rate of return of the national stock exchange where } \\
\text { bank } i \text { is located }(P X=\text { stock index })\end{array}$ \\
$S I Z E_{i}$ & $=P X_{i, t} \cdot S h_{i, t} \cdot D E X_{i, t}$ & $\begin{array}{l}\text { Daily market capitalization of bank } i \text { ( } P X=\text { stock price in } \\
\text { local current units; } S h=\text { number of shares; } D E X=\text { daily } \\
\text { exchange rate })\end{array}$ \\
$S I Z E_{m}$ & $=\sum_{i=1}^{122} S I Z E_{i} \quad i \notin U K$ & $\begin{array}{l}\text { Daily market capitalization of all banks in the sample } \\
\text { excluding UK banks }\end{array}$ \\
$S I Z E R E L$ & $=\frac{S I Z E_{i, t}}{S I Z E_{m, t}}$ & Relative market capitalization of bank $i$
\end{tabular}

Notes: $S . D .=$ standard deviation; $Q 1=$ first quartile $Q 3=$ third quartile. 
Table 3 - Announcement impact on banks' rates of return: dummy variables.

\begin{tabular}{|c|c|c|c|c|c|c|c|}
\hline $\begin{array}{r}\text { Approach } \\
\text { Model } \\
\text { Estimator } \\
\text { Bank/Time Effects } \\
\text { VARIABLE }\end{array}$ & $\begin{array}{l}\text { Parameter } \\
\text { Pre-Crisis } \\
\mathrm{LSDV}^{(\mathrm{a})} \\
\mathrm{D}_{\mathrm{i}}+\mathrm{D}_{\mathrm{t}} \\
(1) \\
\end{array}$ & $\begin{array}{c}- \\
\text { Eq. (1) } \\
\text { OLS } \\
-- \\
(2)\end{array}$ & $\begin{array}{l}\text { Parameter } \\
\text { Eq. (1) } \\
\text { LSDV } \\
D_{i} \\
(3) \\
\end{array}$ & $\begin{array}{l}\text { Parameter } \\
\text { Eq. (1) } \\
\text { LSDV } \\
D_{\mathrm{t}} \\
(4)\end{array}$ & $\begin{array}{l}\text { Parameter } \\
\text { Eq. (1) } \\
\text { LSDV } \\
\mathrm{D}_{\mathrm{i}}+\mathrm{D}_{\mathrm{t}} \\
(5)\end{array}$ & $\begin{array}{l}\text { Parameter } \\
\text { Eq. (2) } \\
\text { LSDV } \\
\mathrm{D}_{\mathrm{i}}+\mathrm{D}_{\mathrm{t}} \\
(6)\end{array}$ & $\begin{array}{l}\text { Parameter } \\
\text { Eq. (3) } \\
\text { LSDV } \\
D_{\mathrm{i}}+\mathrm{D}_{\mathrm{t}} \\
(7)\end{array}$ \\
\hline$R_{m}$ & $1.334 * * *$ & $1.408 * * *$ & $1.407 * * *$ & $1.315 * * *$ & $1.312 * * *$ & $1.312 * * *$ & $1.314 * * *$ \\
\hline SIZEREL & $0.0202 *$ & $0.0259 \#$ & $0.562 * * *$ & $0.0257^{*}$ & $0.582 * * *$ & $0.588 * * *$ & $0.583 * * *$ \\
\hline$G^{A L L}$ & & $0.00615 * * *$ & $0.00601 * * *$ & $0.00281 * * *$ & $0.00260 * *$ & $0.00342 * * *$ & \\
\hline$R_{m} * G^{A L L}$ & & $-0.0584 * * *$ & $-0.0582 * * *$ & $0.108 * * *$ & $0.109 * * *$ & $0.110 * * *$ & \\
\hline$S I Z E R E L * G^{A L L}$ & & & & & & $-0.108 \#$ & \\
\hline$G^{C A P}$ & & & & & & & $0.00315 * * *$ \\
\hline$R_{m} * G^{C A P}$ & & & & & & & $0.249 * * *$ \\
\hline$G^{G U A}$ & & & & & & & 0.000940 \\
\hline$R_{m} * G^{G U A}$ & & & & & & & $-0.260 * * *$ \\
\hline$S^{A L L}$ & & $-0.00518 * * *$ & $-0.00493 * * *$ & $-0.00354 * *$ & $-0.00321 *$ & -0.00286 & \\
\hline$R_{m} * S^{A L L}$ & & $0.198 * * *$ & $0.193 * * *$ & $0.255 * * *$ & $0.250 * * *$ & $0.251 * * *$ & \\
\hline SIZEREL $* S^{A L L}$ & & & & & & -0.0396 & \\
\hline$S^{C A P}$ & & & & & & & $-0.00499 * * *$ \\
\hline$R_{m} * S^{C A P}$ & & & & & & & $0.271 * * *$ \\
\hline$S^{G U A}$ & & & & & & & -0.000672 \\
\hline$R_{m} * S^{G U A}$ & & & & & & & $0.412 * * *$ \\
\hline Constant & -0.00007 & $-0.000405^{*}$ & -0.00312 & -0.00427 & $-0.00709 *$ & $-0.00715^{*}$ & $-0.00700^{*}$ \\
\hline Bank/Time Dummies & Yes\Yes & NolNo & Yes\No & NolYes & Yes\Yes & Yes $\backslash$ Yes & Yes\Yes \\
\hline Observations & 32,247 & 37,835 & 37,835 & 37,835 & 37,835 & 37,835 & 37,835 \\
\hline Number of groups: banks & -- & -- & 115 & -- & 115 & 115 & 115 \\
\hline Number of groups: days & -- & -- & -- & 329 & 329 & 329 & 329 \\
\hline Adjusted $\mathrm{R}^{2}$ & 0.455 & 0.440 & 0.439 & 0.489 & 0.488 & 0.488 & 0.489 \\
\hline F Test & 13,475 & 4,953 & 4,952 & 2,083 & 2,088 & 1,566 & 1,263 \\
\hline Prob $>$ F & 0 & 0 & 0 & 0 & 0 & 0 & 0 \\
\hline Ann. Wald Test & & 21.38 & 20.21 & 12.15 & 11.46 & 8.04 & 15.29 \\
\hline Ann. Wald Prob $>$ F & & 0 & 0 & 0 & 0 & 0 & 0 \\
\hline LR Test & & & 63.38 & 3,791 & 3,865 & 3,865 & 3,666 \\
\hline LR Test Prob $>$ chi 2 & & & 1.000 & 0 & 0 & 0 & 0 \\
\hline \multicolumn{8}{|c|}{$\begin{array}{l}\text { Notes: Data on } 18 \text { countries from 15/09/2008 to 31/12/2009; Pre-Crisis period goes from 31/07/2007 to 14/09/2008. Estimators: OLS = Ordinary } \\
\text { Least Squares; } L S D V=\text { Least Square Dummy Variables. (a) same coefficients and similar test results using OLS without bank/time dummies. } \\
\text { Bank/Time Effects: } D_{i}=\text { bank dummies; } D_{t}=\text { day dummies. Variables: } R_{i}=\text { bank's rate of return (dependent variable); } R_{m}=\text { market's rate of return; } \\
\text { SIZEREL = capitalization value of bank } i \text { relative to capitalization of all banks in the sample; } G=\text { general announcements; } S=\text { specific } \\
\text { announcements; } A L L=\text { all types; } C A P=\text { capital injections; } G U A=\text { asset and debt liabilities. Tests: F Test: joint statistical significance of the full } \\
\text { specification; Ann. Wald: joint statistical significance of announcements (bold variables); LR Test: Likelihood Ratio test of specification without } \\
\text { dummies vs specification with firm and/or time dummies. }{ }^{* * *} \mathrm{p}<0.01 * * \mathrm{p}<0.05 * \mathrm{p}<0.10 \# \mathrm{p}<0.15 \text {. }\end{array}$} \\
\hline
\end{tabular}


Table 4 - Announcement impact on banks' rates of return: FGLS correction.

\begin{tabular}{|c|c|c|c|c|c|c|c|}
\hline $\begin{array}{r}\text { Appraoch } \\
\text { Model } \\
\text { Estimator } \\
\text { Bank/Time Effects } \\
\text { VARIABLE }\end{array}$ & \begin{tabular}{c|}
$\mathrm{SE}$ \\
Pre-Crisis \\
$\mathrm{FGLS}^{(\mathrm{a})}$ \\
$\mathrm{AR}(1)+\mathrm{XC}_{\mathrm{i}}$ \\
$(1)$ \\
\end{tabular} & $\begin{array}{l}\text { Parameter } \\
\text { Eq. (1) } \\
\text { OLS } \\
-- \\
(2) \\
\end{array}$ & $\begin{array}{l}\text { SE } \\
\text { Eq. (1) } \\
\text { FGLS } \\
\text { AR(1) } \\
\text { (3) } \\
\end{array}$ & $\begin{array}{c}\mathrm{SE} \\
\text { Eq. (1) } \\
\text { FGLS } \\
\mathrm{XC}_{\mathrm{i}} \\
(4) \\
\end{array}$ & $\begin{array}{c}\text { SE } \\
\text { Eq. (1) } \\
\text { FGLS } \\
\text { AR(1)+XC } \\
\quad(5) \\
\end{array}$ & $\begin{array}{c}\mathrm{SE} \\
\text { Eq. }(2) \\
\text { FGLS } \\
\mathrm{AR}(1)+\mathrm{XC}_{\mathrm{i}} \\
(6) \\
\end{array}$ & $\begin{array}{c}\text { SE } \\
\text { Eq. (3) } \\
\text { FGLS } \\
\text { AR(1)+XC } \mathrm{X}_{\mathrm{i}} \\
\quad(7) \\
\end{array}$ \\
\hline$R_{m}$ & $1.264 * * *$ & $1.408 * * *$ & $1.403 * * *$ & $1.315 * * *$ & $1.314 * * *$ & $1.314 * * *$ & $1.317 * * *$ \\
\hline SIZEREL & $0.589 * * *$ & $0.0259 \#$ & $0.0284^{*}$ & $0.0166^{* *}$ & $0.0188^{* *}$ & $0.0202 * * *$ & $0.0204 * * *$ \\
\hline $\begin{array}{l}G^{A L L} \\
R_{m} * G^{A L L} \\
\operatorname{SIZEREL} * G^{A L L} \\
G^{C A P} \\
R_{m} * G^{C A P} \\
G^{G U A} \\
R_{m} * G^{G U A}\end{array}$ & & $\begin{array}{l}0.00615 * * * \\
-\mathbf{0 . 0 5 8 4} * * *\end{array}$ & $\begin{array}{c}0.00596 * * * \\
-0.0518 * *\end{array}$ & $\begin{array}{l}0.00426 * * * \\
-0.0355 * *\end{array}$ & $\begin{array}{c}0.00415 * * * \\
-0.0255 \#\end{array}$ & $\begin{array}{c}0.00451 * * * \\
-0.0248 \# \\
-0.0434\end{array}$ & $\begin{array}{c}0.00556 * * * \\
0.189 * * * \\
0.000497 \\
-0.356 * * *\end{array}$ \\
\hline $\begin{array}{l}S^{A L L} \\
R_{m} * S^{A L L} \\
\operatorname{SIZEREL} * S^{A L L} \\
S^{C A P} \\
R_{m} * S^{C A P} \\
S^{G U A} \\
R_{m} * S^{G U A}\end{array}$ & & $\begin{array}{c}-0.00518 * * * \\
0.198 * * *\end{array}$ & $\begin{array}{c}-0.00507 * * * \\
0.194 * * *\end{array}$ & $\begin{array}{c}-0.00246 * * \\
0.196 * * *\end{array}$ & $\begin{array}{c}-0.00230 * * \\
0.189 * * *\end{array}$ & $\begin{array}{c}-0.00257 * * \\
0.189 * * * \\
0.0249\end{array}$ & $\begin{array}{c}-0.00254 * * \\
0.191 * * * \\
-0.00466 * \\
0.380^{*} * *\end{array}$ \\
\hline Constant & -0.000532 & $-0.000405^{*}$ & $-0.000361 \#$ & $-9.90 e-05$ & $-2.90 e-05$ & $-5.15 e-05$ & -0.000146 \\
\hline Bank/Time Dummies & NolNo & No $\backslash$ No & No $\backslash$ No & NolNo & NolNo & NolNo & No $\backslash$ No \\
\hline Observations & 32,247 & 37,835 & 37,835 & 37,835 & 37,835 & 37,835 & 37,835 \\
\hline Number of groups: banks & 115 & -- & 115 & 115 & 115 & 115 & 115 \\
\hline Number of groups: days & 329 & -- & 329 & 329 & 329 & 329 & 329 \\
\hline Adjusted $\mathrm{R}^{2}$ & 0.515 & 0.440 & 0.440 & 0.440 & 0.440 & 0.440 & 0.444 \\
\hline F Test & 86.91 & 4,953 & 30,027 & 28,916 & 30,315 & 30,372 & 29,575 \\
\hline Prob $>$ F & 0 & 0 & 0 & 0 & 0 & 0 & 0 \\
\hline Ann. Wald Test & & 21.38 & 82.95 & 83.29 & 73.37 & 75.32 & 355.7 \\
\hline Ann. Wald Prob $>$ F & & 0 & 0 & 0 & 0 & 0 & 0 \\
\hline A-Corr. Test & & & 12.90 & & 12.90 & 13.08 & 10.70 \\
\hline A-Corr. Prob $>$ F & & & 0.0004 & & 0.0004 & 0.000400 & 0.0014 \\
\hline X-Corr. Test & & & & 32,650 & 32,572 & 32,597 & 32,639 \\
\hline X-Corr. Prob > chi2 & & & & 0 & 0 & 0 & 0 \\
\hline $\begin{array}{l}\text { Notes: Data on } 18 \text { countries from } \\
\text { from Table } 2 \text { to compare results. } \\
\text { Squares; } F G L S=\text { Feasible Gene } \\
\text { standard errors. Variables: } R_{i}=1 \\
\text { relative to capitalization of all ban } \\
G U A=\text { asset and debt liabilities } \\
\text { announcements (bold variables); } \\
* \mathrm{p}<0.10 \# \mathrm{p}<0.15\end{array}$ & $\begin{array}{l}\text { standard er } \\
\text { d Least Sq } \\
\text { s rate of re } \\
\text { the sample } \\
\text { ts: F Test: }\end{array}$ & $\begin{array}{l}\text { (a) similar } \mathrm{r} \\
\text { (dependent } \\
\text { general anr } \\
\text { t statistical }\end{array}$ & $\begin{array}{l}\text { period goc } \\
\text { using } F G L \\
\text { ects: } A R(1) \\
\text { ble); } R_{m}= \\
\text { ements; } S= \\
\text { ficance of }\end{array}$ & $\begin{array}{l}31 / 07 / 2 \\
A R(1) \text { o } \\
\text { lag aut } \\
\text { t's rate o } \\
\text { fic annou } \\
\text { ll specifi }\end{array}$ & $\begin{array}{l}14 / 09 / 20 \\
S \text { with } X C_{i} \\
\text { lated stan } \\
\text { n; SIZERL } \\
\text { nts; } A L L= \\
\text { Ann. Wa }\end{array}$ & $\begin{array}{l}\text { olumn }(1) \mathrm{r} \\
\text { mators: } O L \\
\text { errors; } X C_{i} \\
\text { capitalizati } \\
\text { ppes; } C A P=\end{array}$ & $\begin{array}{l}\text { S Column (1) } \\
\text { rdinary Least } \\
\text { oss-correlated } \\
\text { lue of bank } i \\
\text { tal injections; } \\
\text { gnificance of } \\
01 * * p<0.05\end{array}$ \\
\hline
\end{tabular}


Table 5 - Announcement impact on banks' rates of return: clustered standard errors.

\begin{tabular}{|c|c|c|c|c|c|c|c|}
\hline $\begin{array}{r}\text { Approach } \\
\text { Model } \\
\text { Estimator } \\
\text { Bank/Time Effects } \\
\text { VARIABLE }\end{array}$ & $\begin{array}{c}\mathrm{SE} \\
\text { Pre-Crisis } \\
\mathrm{OLS}^{(\mathrm{a})} \\
\mathrm{CL}_{\mathrm{i}}+\mathrm{CL}_{\mathrm{t}} \\
\text { (1) }\end{array}$ & $\begin{array}{l}\text { Parameter } \\
\text { Eq. (1) } \\
\text { LSDV } \\
\mathrm{D}_{\mathrm{i}}+\mathrm{D}_{\mathrm{t}} \\
(2)\end{array}$ & $\begin{array}{c}\text { SE } \\
\text { Eq. }(1) \\
\text { LSDV } \\
\text { CL }_{\mathrm{i}}+\mathrm{D}_{\mathrm{t}} \\
\quad(3)\end{array}$ & $\begin{array}{c}\mathrm{SE} \\
\text { Eq. (1) } \\
\text { LSDV } \\
\mathrm{D}_{\mathrm{i}}+\mathrm{CL}_{\mathrm{t}} \\
\quad(4)\end{array}$ & $\begin{array}{c}\text { SE } \\
\text { Eq. (1) } \\
\text { OLS } \\
\mathrm{CL}_{\mathrm{i}}+\mathrm{CL}_{\mathrm{t}} \\
(5) \\
\end{array}$ & $\begin{array}{c}\text { SE } \\
\text { Eq. (2) } \\
\text { OLS } \\
\text { CL }_{\mathrm{i}}+\mathrm{CL}_{\mathrm{t}} \\
(6) \\
\end{array}$ & $\begin{array}{c}\text { SE } \\
\text { Eq. (3) } \\
\text { OLS } \\
\text { CL }_{\mathrm{i}}+\mathrm{CL}_{\mathrm{t}} \\
(7) \\
\end{array}$ \\
\hline$R_{m}$ & $1.334 * * *$ & $1.312 * * *$ & $1.315^{* * *}$ & $1.407 * * *$ & $1.408 * * *$ & $1.408 * * *$ & $1.411 * * *$ \\
\hline SIZEREL & $0.0202 * *$ & $0.582 * * *$ & $0.0257 * * *$ & $0.562 * * *$ & $0.0259 * *$ & $0.0302 * * *$ & $0.0291 * * *$ \\
\hline$G^{A L L}$ & & $0.00260 * *$ & $0.00281 * *$ & 0.00601 & 0.00615 & 0.00691 & \\
\hline$R_{m}^{*} G^{A L L}$ & & $0.109 * * *$ & $0.108 * * *$ & -0.0582 & -0.0584 & -0.0574 & \\
\hline SIZEREL * $G^{A L L}$ & & & & & & $-0.0986 * * *$ & \\
\hline$G^{C A P}$ & & & & & & & $0.00703 \#$ \\
\hline$R_{m} * G^{C A P}$ & & & & & & & $0.267^{*}$ \\
\hline$G^{G U A}$ & & & & & & & 0.00198 \\
\hline$R_{m} * G^{G U A}$ & & & & & & & $-0.536 * * *$ \\
\hline$S^{A L L}$ & & $-0.00321 *$ & $-0.00354 *$ & $-0.00493 \#$ & $-0.00518 *$ & $-0.00566 *$ & \\
\hline$R_{m} * S^{A L L}$ & & $0.250 * * *$ & $0.255^{*}$ & 0.193 & 0.198 & 0.196 & \\
\hline SIZEREL $* S^{A L L}$ & & & & & & 0.0513 & \\
\hline$S^{C A P}$ & & & & & & & $-0.00682 * *$ \\
\hline$R_{m} * S^{C A P}$ & & & & & & & 0.221 \\
\hline$S^{G U A}$ & & & & & & & -0.00286 \\
\hline$R_{m} * S^{G U A}$ & & & & & & & $0.396 *$ \\
\hline Constant & -0.00007 & $-0.00709 *$ & -0.00427 & -0.00312 & -0.000405 & -0.000439 & -0.000443 \\
\hline Bank/Time Dummies & No\No & Yes $\backslash$ Yes & Yes $\backslash$ Yes & Yes\Yes & No\No & No $\backslash$ No & NolNo \\
\hline Observations & 32,247 & 37,835 & 37,835 & 37,835 & 37,835 & 37,835 & 37,835 \\
\hline Number of groups: banks & 115 & -- & 115 & -- & 115 & 115 & 115 \\
\hline Number of groups: days & 329 & -- & -- & 329 & 329 & 329 & 329 \\
\hline Adjusted $\mathrm{R}^{2}$ & 0.455 & 0.488 & 0.489 & 0.439 & 0.440 & 0.440 & 0.444 \\
\hline F Test & 341.2 & 2,088 & 277.4 & 183.1 & 96.46 & 86.19 & 73.88 \\
\hline Prob $>$ F & 0 & 0 & 0 & 0 & 0 & 0 & 0 \\
\hline Ann. Wald Test & & 11.46 & 4.72 & 1.78 & 1.96 & 11.47 & 3.38 \\
\hline Ann. Wald Prob $>$ F & & 0 & 0.0014 & 0.133 & 0.0982 & 0 & 0.0013 \\
\hline $\begin{array}{l}\text { Notes: Data on } 18 \text { countries from } \\
\text { Column (4) from Table } 2 \text { to compa } \\
L S D V=\text { Least Square Dummy Var } \\
C L_{t}=\text { day-clustered standard error } \\
\text { capitalization value of bank } i \text { relat } \\
A L L=\text { all types; } C A P=\text { capital inje } \\
\text { Ann. Wald: joint statistical signific }\end{array}$ & $\begin{array}{l}09 / 2008 \text { to } \\
\text { esults. } \mathrm{SE}= \\
\text { es. Bank/T } \\
\text { Jariables: } \\
\text { to capitaliza } \\
\text { ns; } G U A=\end{array}$ & $\begin{array}{l}2 / 2009 ; \\
\text { lard erro } \\
\text { ffects: } D \\
\text { ank's rat } \\
\text { ff all bar } \\
\text { and debt }\end{array}$ & $\begin{array}{l}\text { Crisis peri } \\
\text { i) similar } r \\
\text { ank dumn } \\
\text { return }(d \\
\text { in the sam } \\
\text { ilities. Tes }\end{array}$ & $\begin{array}{l}\text { oes from } \\
\text { s using } L \\
D_{t}=\text { day } \\
\text { dent vari } \\
G=\text { gene }\end{array}$ & $\begin{array}{l}07 / 2007 \text { to } \\
\text {. Estimato } \\
\text { mmies; } C L_{i} \\
\text { ) } R_{m}=\mathrm{ma} \\
\text { announcem } \\
\text { atistical sig }\end{array}$ & $\begin{array}{l}09 / 2008 \\
L S=\text { Ordi } \\
\text { ank-cluste } \\
\text { 's rate of } \\
S=\text { speci } \\
\text { ance of th }\end{array}$ & $\begin{array}{l}\text { in (1) reports } \\
\text { east Squares, } \\
\text { indard errors, } \\
\text {; SIZEREL }= \\
\text { houncements, } \\
\text { specification, }\end{array}$ \\
\hline
\end{tabular}


Table 6 - Announcement impact on banks' rates of return: Fama-MacBeth and Driscoll-Kraay standard errors.

\begin{tabular}{|c|c|c|c|c|c|c|c|}
\hline $\begin{array}{r}\text { Approach } \\
\text { Model } \\
\text { Estimator } \\
\text { Bank/Time Effects } \\
\text { VARIABLE }\end{array}$ & $\begin{array}{c}\text { SE } \\
\text { Pre-Crisis } \\
\text { OLS }^{(a)} \\
\mathrm{DK}_{\mathrm{i}+\mathrm{t}} \\
(1)\end{array}$ & $\begin{array}{l}\text { Parameter } \\
\text { Eq. (1) } \\
\text { FGLS } \\
\mathrm{XC}_{\mathrm{i}}+\mathrm{AR}(1) \\
\text { (2) }\end{array}$ & $\begin{array}{l}\text { SE } \\
\text { Eq. (1) } \\
\text { OLS } \\
\text { FM }_{i} \\
(3)\end{array}$ & $\begin{array}{c}\text { SE } \\
\text { Eq. (1) } \\
\text { OLS } \\
\text { FM }_{t} \\
(4)\end{array}$ & $\begin{array}{c}\text { SE } \\
\text { Eq. (1) } \\
\text { OLS } \\
\text { DK }_{\mathrm{i}+\mathrm{t}} \\
(5)\end{array}$ & $\begin{array}{c}\text { SE } \\
\text { Eq. (2) } \\
\text { OLS } \\
\text { DK }_{i+t} \\
(6)\end{array}$ & $\begin{array}{c}\text { SE } \\
\text { Eq. (3) } \\
\text { OLS } \\
\text { DK }_{\mathrm{i}+\mathrm{t}} \\
(7)\end{array}$ \\
\hline$R_{m}$ & $1.334 * * *$ & $1.314 * * *$ & $1.418 * * *$ & $1.294 * * *$ & $1.408 * * *$ & $1.408 * * *$ & $1.411 * * *$ \\
\hline SIZEREL & $0.0202 *$ & $0.0188^{* *}$ & $7.742 * * *$ & 0.0216 & $0.0259 \#$ & $0.0302 *$ & $0.0291 *$ \\
\hline$G^{A L L}$ & & $0.00415 * * *$ & $0.00482 * * *$ & 0.000624 & $0.00615 * *$ & $0.00691 * *$ & \\
\hline$R_{m} * G^{A L L}$ & & $-0.0255 \#$ & $-0.141 * * *$ & 0.0682 & -0.0584 & -0.0574 & \\
\hline$S I Z E R E L * G^{A L L}$ & & & & & & -0.0986 & \\
\hline$G^{C A P}$ & & & & & & & $0.00703 * *$ \\
\hline$R_{m} * G^{C A P}$ & & & & & & & $0.267 \#$ \\
\hline$G^{G U A}$ & & & & & & & 0.00198 \\
\hline$R_{m} * G^{G U A}$ & & & & & & & $-0.536 * * *$ \\
\hline$S^{A L L}$ & & $-0.00230 * *$ & $-0.00278 * * *$ & -0.00386 & $-0.00518 \#$ & $-0.00566 \#$ & \\
\hline$R_{m} * S^{A L L}$ & & $0.189 * * *$ & -0.0137 & 0.0264 & 0.198 & 0.196 & \\
\hline$S I Z E R E L * S^{A L L}$ & & & & & & 0.0513 & \\
\hline$S^{C A P}$ & & & & & & & $-0.00682 * *$ \\
\hline$R_{m} * S^{C A P}$ & & & & & & & $0.221 \#$ \\
\hline$S^{G U A}$ & & & & & & & -0.00286 \\
\hline$R_{m} * S^{G U A}$ & & & & & & & 0.396 \\
\hline Constant & -0.00007 & $-2.90 \mathrm{e}-05$ & $-0.0163 * * *$ & -0.000770 & -0.000405 & -0.000439 & -0.000443 \\
\hline Bank/Time Dummies & Yes $\backslash$ Yes & NolNo & Yes\Yes & Yes $\backslash$ Yes & Yes $\backslash$ Yes & Yes $\backslash$ Yes & Yes $\backslash$ Yes \\
\hline Observations & 32,247 & 37,835 & 37,835 & 37,835 & 37,835 & 37,835 & 37,835 \\
\hline Number of groups: banks & 115 & 115 & 115 & -- & 115 & 115 & 115 \\
\hline Number of groups: days & 329 & 329 & -- & 329 & 329 & 329 & 329 \\
\hline Adjusted $\mathrm{R}^{2}$ & 0.455 & 0.440 & 0.538 & 0.284 & 0.440 & 0.440 & 0.444 \\
\hline F Test & 398.9 & 30,315 & 211.5 & 252.7 & 87.98 & 67.84 & 90.50 \\
\hline Prob $>$ F & 0 & 0 & 0 & 0 & 0 & 0 & 0 \\
\hline Ann. Wald Test & & 73.37 & 12.33 & 0.37 & 2.73 & 1.85 & 3.97 \\
\hline Ann. Wald Prob $>$ F & & 0 & 0 & 0.8300 & 0.0327 & 0.0947 & 0.0003 \\
\hline
\end{tabular}

Notes: Data on 18 countries from 15/09/2008 to 31/12/2009; Pre-Crisis period goes from 31/07/2007 to 14/09/2008. Column (1) reports Column (4) from Table 3 to compare results. $S E=$ standard errors. (a) $R_{m}$ coefficient equal to 1.206 and SIZEREL coefficients marginally not-significant using $F M_{i}$ or $F M_{t}$. Estimators: $O L S=$ Ordinary Least Squares; $F G L S=$ Feasible Generalized Least Squares. Bank/Time Effects: $A R(I)=$ one lag autoregressive standard errors. $X C_{i}=$ cross-correlated standard errors; $F M_{i}=$ Fama-MacBeth standard errors on banks; $F M_{t}=$ Fama-MacBeth standard errors on days; $D K_{i+t}=$ Driscoll-Kraay standard errors. Variables: $R_{i}=$ bank's rate of return (dependent variable); $R_{m}=$ market's rate of return; SIZEREL = capitalization value of bank $i$ relative to capitalization of all banks in the sample; $G=$ general announcements; $S=$ specific announcements; $A L L=$ all types; $C A P=$ capital injections; $G U A=$ asset and debt liabilities. Tests: $\mathrm{F}$ Test: joint statistical significance of the full specification; Ann. Wald: joint statistical significance of announcements (bold variables). ${ }^{* * *} \mathrm{p}<0.01 * * \mathrm{p}<0.05 * \mathrm{p}<0.10 \# \mathrm{p}<0.15$ 
Table 7 - Announcement impact on banks' rates of return: mixed approach over the entire period.

\begin{tabular}{|c|c|c|c|c|c|c|c|}
\hline $\begin{array}{r}\text { Approach } \\
\text { Model } \\
\text { Estimator } \\
\text { Bank/Time Effects } \\
\text { VARIABLE }\end{array}$ & $\begin{array}{l}\text { Mixed } \\
\text { Pre-Crisis } \\
\mathrm{LSDV}^{(\mathrm{a})} \\
\mathrm{D}_{\mathrm{i}+\mathrm{t}}+\mathrm{CL}_{\mathrm{i}+\mathrm{t}} \\
\text { (1) }\end{array}$ & $\begin{array}{c}\text { Mixed } \\
\text { Eq. (1) } \\
\text { LSDV } \\
\text { D }_{\mathrm{i}+\mathrm{t}}+\mathrm{CL}_{\mathrm{i}+\mathrm{t}} \\
\text { (2) }\end{array}$ & $\begin{array}{c}\text { Mixed } \\
\text { Eq. (2) } \\
\text { LSDV } \\
\mathrm{D}_{\mathrm{i}+\mathrm{t}}+\mathrm{CL}_{\mathrm{i}+\mathrm{t}} \\
\text { (3) }\end{array}$ & $\begin{array}{c}\text { Mixed } \\
\text { Eq. (3) } \\
\text { LSDV } \\
\text { D }_{\mathrm{i}+\mathrm{t}}+\mathrm{CL}_{\mathrm{i}+\mathrm{t}} \\
(4)\end{array}$ & $\begin{array}{c}\text { Mixed } \\
\text { Eq. (1) } \\
\text { LSDV } \\
\mathrm{D}_{\mathrm{i}+\mathrm{t}}+\mathrm{DK}_{\mathrm{i}+\mathrm{t}} \\
(5)\end{array}$ & $\begin{array}{c}\text { Mixed } \\
\text { Eq. (2) } \\
\text { LSDV } \\
\mathrm{D}_{\mathrm{i}+\mathrm{t}}+\mathrm{DK}_{\mathrm{i}+\mathrm{t}} \\
(6)\end{array}$ & $\begin{array}{c}\text { Mixed } \\
\text { Eq. (3) } \\
\text { LSDV } \\
\mathrm{D}_{\mathrm{i}+\mathrm{t}}+\mathrm{DK}_{\mathrm{i}+\mathrm{t}} \\
\quad(7) \\
\end{array}$ \\
\hline$R_{m}$ & $1.334 * * *$ & $1.312 * * *$ & $1.312 * * *$ & $1.314 * * *$ & $1.312 * * *$ & $1.312 * * *$ & $1.314 * * *$ \\
\hline SIZEREL & $0.0202 * *$ & $0.582 * * *$ & $0.588 * * *$ & $0.583 * * *$ & $0.582 * * *$ & $0.588 * * *$ & $0.583 * * *$ \\
\hline$G^{A L L}$ & & 0.00260 & 0.00342 & & 0.00260 & 0.00342 & \\
\hline$R_{m} * G^{A L L}$ & & 0.109 & 0.110 & & 0.109 & 0.110 & \\
\hline$S I Z E R E L * G^{A L L}$ & & & $-0.108 * * *$ & & & $-0.108 *$ & \\
\hline$G^{C A P}$ & & & & 0.00315 & & & 0.00315 \\
\hline$R_{m} * G^{C A P}$ & & & & $0.249 *$ & & & $0.249 \#$ \\
\hline$G^{G U A}$ & & & & 0.000940 & & & 0.000940 \\
\hline$R_{m}^{*} G^{G U A}$ & & & & $-0.260 * *$ & & & $-0.260 *$ \\
\hline$S^{A L L}$ & & -0.00321 & -0.00286 & & -0.00321 & -0.00286 & \\
\hline$R_{m} * S^{A L L}$ & & $0.250 *$ & $0.251 *$ & & $0.250 *$ & $0.251 * *$ & \\
\hline SIZEREL $* S^{A L L}$ & & & -0.0396 & & & -0.0396 & \\
\hline$S^{C A P}$ & & & & $-0.00499 *$ & & & $-0.00499 *$ \\
\hline$R_{m} * S^{C A P}$ & & & & $0.271 *$ & & & $0.271 * *$ \\
\hline$S^{G U A}$ & & & & -0.000672 & & & -0.000672 \\
\hline$R_{m} * S^{G U A}$ & & & & $0.412 *$ & & & 0.412 \\
\hline Constant & -0.00007 & $-0.00709 * * *$ & $-0.00715 * * *$ & $-0.00700 * * *$ & $-0.00709 * * *$ & $-0.00715^{* * *}$ & $-0.00700 * * *$ \\
\hline Bank/Time Dummies & Yes $\backslash$ Yes & Yes $\backslash$ Yes & Yes $\backslash$ Yes & Yes $\backslash$ Yes & Yes $\backslash$ Yes & Yes $\backslash$ Yes & Yes $\backslash$ Yes \\
\hline Observations & 32,247 & 37,835 & 37,835 & 37,835 & 37,835 & 37,835 & 37,835 \\
\hline Number of groups: banks & 115 & 115 & 115 & 115 & 115 & 115 & 115 \\
\hline Number of groups: days & 329 & 329 & 329 & 329 & 329 & 329 & 329 \\
\hline Adjusted $\mathrm{R}^{2}$ & 0.455 & 0.488 & 0.488 & 0.489 & 0.494 & 0.494 & 0.495 \\
\hline F Test & 341.2 & 97.52 & 90.15 & 66.97 & 85.97 & 69.56 & 53.65 \\
\hline Prob $>$ F & 0 & 0 & 0 & 0 & 0 & 0 & 0 \\
\hline
\end{tabular}

Notes: Data on 18 countries from 15/09/2008 to 31/12/2009; Pre-Crisis period goes from 31/07/2007 to 14/09/2008. Mixed = dummy + standard error approach. (a) similar results using $D K_{i+t}$. Estimators: $L S D V=$ Least Squares Dummy Variables. Bank/Time Effects: $D_{i}=$ bank dummies; $D_{t}=$ day dummies; $C L_{i}=$ bank-clustered standard errors; $C L_{t}=$ day-clustered standard errors; $D K_{i+t}=$ Driscoll-Kraay standard errors. Variables: $R_{i}=$ bank's rate of return (dependent variable); $R_{m}=$ market's rate of return; SIZEREL = capitalization value of bank $i$ relative to capitalization of all banks in the sample; $G=$ general announcements; $S=$ specific announcements; $A L L=$ all types; $C A P=$ capital injections; $G U A=$ asset and debt liabilities. Tests: $\mathrm{F}$ Test: joint statistical significance of the full specification; Ann. Wald: joint statistical significance of announcements (bold variables). ${ }^{* * *} \mathrm{p}<0.01 * *$ $\mathrm{p}<0.05 * \mathrm{p}<0.10 \# \mathrm{p}<0.15$ 
Table 8 - Announcement impact on banks' rates of return: different sub-periods and sub-samples.

\begin{tabular}{|c|c|c|c|c|c|c|c|c|c|}
\hline \multirow{6}{*}{$\begin{array}{rr}\text { Approach } \\
\text { Model } \\
\text { Estimator } \\
\text { VARIABLE } \quad \text { Bank/Time Effects } \\
\end{array}$} & \multicolumn{3}{|c|}{ Turbulent phase of the crisis } & \multicolumn{3}{|c|}{ US (whole period) } & \multicolumn{3}{|c|}{ Europe (whole period) } \\
\hline & Mixed & Mixed & Mixed & Mixed & Mixed & Mixed & Mixed & Mixed & Mixed \\
\hline & Eq. (1) & Eq. (2) & Eq. (3) & Eq. (1) & Eq. (2) & Eq. (3) & Eq. (1) & Eq. (2) & Eq. (3) \\
\hline & LSDV & LSDV & LSDV & LSDV & LSDV & LSDV & LSDV & LSDV & LSDV \\
\hline & $\mathrm{D}_{\mathrm{i}+\mathrm{t}}+\mathrm{CL}_{\mathrm{i}+\mathrm{t}}$ & $\mathrm{D}_{\mathrm{i}+\mathrm{t}}+\mathrm{CL}_{\mathrm{i}+\mathrm{t}}$ & $\mathrm{D}_{\mathrm{i}+\mathrm{t}}+\mathrm{CL}_{\mathrm{i}+\mathrm{t}}$ & $\mathrm{D}_{\mathrm{i}+\mathrm{t}}+\mathrm{DK}_{\mathrm{i}+\mathrm{t}}$ & $\mathrm{D}_{\mathrm{i}+\mathrm{t}}+\mathrm{DK}_{\mathrm{i}+\mathrm{t}}$ & $\mathrm{D}_{\mathrm{i}+\mathrm{t}}+\mathrm{DK}_{\mathrm{i}+\mathrm{t}}$ & $\mathrm{D}_{\mathrm{i}+\mathrm{t}}+\mathrm{DK}_{\mathrm{i}+\mathrm{t}}$ & $\mathrm{D}_{\mathrm{i}+\mathrm{t}}+\mathrm{DK}_{\mathrm{i}+\mathrm{t}}$ & $\mathrm{D}_{\mathrm{i}+\mathrm{t}}+\mathrm{DK}_{\mathrm{i}+\mathrm{t}}$ \\
\hline & $(1)$ & $(2)$ & (3) & (4) & $(5)$ & $(6)$ & (7) & $(8)$ & (9) \\
\hline$R_{m}$ & $1.262 * * *$ & $1.262 * * *$ & $1.262 * * *$ & $1.801 * * *$ & $1.801 * * *$ & $1.802 * * *$ & $1.285 * * *$ & $1.285 * * *$ & $1.284 * * *$ \\
\hline SIZEREL & $1.482 * * *$ & $1.522 * * *$ & $1.474 * * *$ & $0.0610^{*}$ & $0.0638 \#$ & $0.0628 *$ & $0.0744 * *$ & $0.0676^{*}$ & $0.0735 * *$ \\
\hline$G^{A L L}$ & 0.00365 & 0.00439 & & $0.00955^{* *}$ & $0.0103 * *$ & & -0.000487 & -0.000901 & \\
\hline$R_{m} * G^{A L L}$ & 0.0452 & 0.0458 & & -0.225 & -0.225 & & $-0.189 * * *$ & $-0.189 * * *$ & \\
\hline SIZEREL ${ }^{*} G^{A L L}$ & & -0.115 & & & -0.104 & & & 0.0733 & \\
\hline$G^{C A P}$ & & & 0.00376 & & & 0.00899\# & & & 0.00263 \\
\hline$R_{m} * G^{C A P}$ & & & 0.130 & & & $0.442 *$ & & & $-0.106 \#$ \\
\hline$G^{G U A}$ & & & 0.00240 & & & 0.00683 & & & -0.00353 \\
\hline$R_{m} * G^{G U A}$ & & & -0.140 & & & $-1.125 * * *$ & & & $-0.137 \#$ \\
\hline$S^{A L L}$ & $-0.00509 \#$ & -0.00138 & & $-0.00852 *$ & $-0.0109 * * *$ & & -0.00211 & -0.00346 & \\
\hline$R_{m} * S^{A L L}$ & $0.309 * *$ & $0.322 * *$ & & -0.204 & -0.210 & & $0.347 \#$ & $0.341 \#$ & \\
\hline SIZEREL $* S^{A L L}$ & & $-0.453 * *$ & & & 0.159 & & & 0.352 & \\
\hline$S^{C A P}$ & & & -0.00612 & & & $-0.00715^{* *}$ & & & -0.00491 \\
\hline$R_{m} * S^{C A P}$ & & & $0.396 * *$ & & & $-0.330 * * *$ & & & 0.505 \\
\hline$S^{G U A}$ & & & 0.000153 & & & -0.0383 & & & -0.000578 \\
\hline$R_{m} * S^{G U A}$ & & & 0.294 & & & $2.143^{* *}$ & & & 0.253 \\
\hline Constant & $-0.0139 * * *$ & $-0.0142 * * *$ & $-0.0138 * * *$ & -0.000514 & -0.000533 & -0.000555 & -0.000457 & -0.000420 & -0.000457 \\
\hline Bank/Time Dummies & Yes\Yes & Yes $\backslash$ Yes & Yes $\backslash$ Yes & Yes $\backslash$ Yes & Yes $\backslash$ Yes & Yes $\backslash$ Yes & Yes $\backslash$ Yes & Yes $\backslash$ Yes & Yes $\backslash$ Yes \\
\hline Observations & 13,800 & 13,800 & 13,800 & 14,476 & 14,476 & 14,476 & 14,805 & 14,805 & 14,805 \\
\hline Number of groups (banks/days) & $115 / 120$ & $115 / 120$ & $115 / 120$ & $44 / 329$ & $44 / 329$ & $44 / 329$ & $45 / 329$ & $45 / 329$ & $45 / 329$ \\
\hline Adjusted $\mathrm{R}^{2}$ & 0.505 & 0.505 & 0.505 & 0.456 & 0.456 & 0.469 & 0.433 & 0.433 & 0.434 \\
\hline F Test & 71.44 & 60.24 & 53.65 & 52.97 & 43.04 & 73.63 & 206.2 & 195.3 & 226.3 \\
\hline Prob $>$ F & 0 & 0 & 0 & 0 & 0 & 0 & 0 & 0 & 0 \\
\hline Ann. Wald Test & 2.193 & 4.604 & 1.268 & 2.203 & 2.418 & 8.277 & 3.237 & 2.664 & 3.346 \\
\hline Ann. Wald Prob $>$ F & 0.0670 & 0.0001 & 0.2550 & 0.0846 & 0.0421 & 0 & 0.0205 & 0.0271 & 0.0044 \\
\hline $\begin{array}{l}\text { Notes: Data on } 18 \text { countries from } 15 / 09 / 200 \\
\text { France, Germany, Greece, Ireland, Italy, Po } \\
\text { Effects: } D_{i}=\text { bank dummies; } D_{t}=\text { day dum } \\
\text { variable); } R_{m}=\text { market's rate of return; SIZE } \\
\text { capital injections; GUA = asset and debt liab } \\
\mathrm{p}<0.10 \# \mathrm{p}<0.15\end{array}$ & $\begin{array}{l}31 / 12 / 2009 ; \mathrm{I} \\
\text { al, Netherlanc } \\
\text { s; } C L_{i}=\text { bank } \\
=\text { capitalizat } \\
\text { s. Tests: F Te }\end{array}$ & $\begin{array}{l}\text { sis period go } \\
\text { rway, Spain, } \\
\text { ered standard } \\
\text { lue of bank } i \\
\text { at statistical s }\end{array}$ & $\begin{array}{l}\text { n 31/07/2007 } \\
\text { n, Switzerla } \\
\text {; } C L_{t}=\text { day- } \\
\text { e to capitaliz } \\
\text { ance of the f }\end{array}$ & $\begin{array}{l}\text { ed standard } \\
\text { f all banks } \\
\text { ification; } A\end{array}$ & $\begin{array}{l}\text { nt phase goe } \\
\text { tandard erro } \\
; D K_{i+t}=\mathrm{D} \\
\text { sample; } G \\
\text { ald: joint sta }\end{array}$ & $\begin{array}{l}\text { 15/09/2008 } \\
\text { roach. Estim } \\
\text { l-Kraay stan } \\
\text { eral announc } \\
1 \text { significanc }\end{array}$ & $\begin{array}{l}/ 03 / 2009 ; \mathrm{Eu} \\
L S D V=\text { Lea } \\
\text { rrors. Variab } \\
\text { s; } S=\text { specifi } \\
\text { nnouncement }\end{array}$ & $\begin{array}{l}\text { ncludes Austri } \\
\text { dares Dummy } \\
i=\text { bank's rate } \\
\text { ouncements; } A l \\
\text { d variables). }\end{array}$ & $\begin{array}{l}\text { gium, Denmark } \\
\text { bles. Bank/Tim } \\
\text { turn (depender } \\
\text { all types; CAP } \\
.01 * * \text { p }<0.05\end{array}$ \\
\hline
\end{tabular}


Table 9 - Announcement impact on banks' rates of return: different event windows.

\begin{tabular}{|c|c|c|c|c|c|c|}
\hline \multirow{5}{*}{$\begin{array}{r}\text { Approach } \\
\text { Model } \\
\text { Estimator } \\
\text { Bank/Time Effects }\end{array}$} & \multicolumn{3}{|c|}{ Shorter Event Windows } & \multicolumn{3}{|c|}{ Longer Event Windows } \\
\hline & Mixed & Mixed & Mixed & Mixed & Mixed & Mixed \\
\hline & Eq. (1) & Eq. (2) & Eq. (3) & Eq. (1) & Eq. (2) & Eq. (3) \\
\hline & LSDV & LSDV & LSDV & LSDV & LSDV & LSDV \\
\hline & $\mathrm{D}_{\mathrm{i}+\mathrm{t}}+\mathrm{CL}_{\mathrm{i}+\mathrm{t}}$ & $\mathrm{D}_{\mathrm{i}+\mathrm{t}}+\mathrm{CL}_{\mathrm{i}+\mathrm{t}}$ & $\mathrm{D}_{\mathrm{i}+\mathrm{t}}+\mathrm{CL}_{\mathrm{i}+\mathrm{t}}$ & $\mathrm{D}_{\mathrm{i}+\mathrm{t}}+\mathrm{CL}_{\mathrm{i}+\mathrm{t}}$ & $\mathrm{D}_{\mathrm{i}+\mathrm{t}}+\mathrm{CL}_{\mathrm{i}+\mathrm{t}}$ & $\mathrm{D}_{\mathrm{i}+\mathrm{t}}+\mathrm{CL} \mathrm{L}_{\mathrm{i}+\mathrm{t}}$ \\
\hline VARIABLE & (1) & (2) & (3) & (4) & (5) & (6) \\
\hline$R_{m}$ & $1.315^{* * *}$ & $1.315^{* * *}$ & $1.320 * * *$ & $1.308^{* * *}$ & $1.308^{* * *}$ & $1.311^{* * *}$ \\
\hline SIZEREL & $0.590 * * *$ & $0.596 * * *$ & $0.589 * * *$ & $0.588 * * *$ & $0.583 * * *$ & $0.589 * * *$ \\
\hline$G^{A L L}$ & 0.000728 & 0.00130 & & 0.000341 & 0.000613 & \\
\hline$R_{m} * G^{A L L}$ & 0.138 & 0.138 & & 0.0948 & 0.0952 & \\
\hline$S I Z E R E L * G^{A L L}$ & & -0.0764 & & & -0.0346 & \\
\hline$G^{C A P}$ & & & 0.00263 & & & 0.000968 \\
\hline$R_{m} * G^{C A P}$ & & & $0.282 * *$ & & & $0.202 *$ \\
\hline$G^{G U A}$ & & & 0.00508 & & & -0.0000389 \\
\hline$R_{m} * G^{G U A}$ & & & $-0.279 * *$ & & & $-0.207 *$ \\
\hline$S^{A L L}$ & -0.00377 & -0.00267 & & -0.00194 & $-0.00321 \#$ & \\
\hline$R_{m} * S^{A L L}$ & 0.187 & $0.192 \#$ & & $0.283^{*}$ & $0.277 *$ & \\
\hline SIZEREL $* S^{A L L}$ & & -0.123 & & & 0.135 & \\
\hline$S^{C A P}$ & & & -0.00395 & & & -0.00178 \\
\hline$R_{m} * S^{C A P}$ & & & 0.146 & & & $0.281 *$ \\
\hline$S^{G U A}$ & & & -0.00609 & & & -0.00415 \\
\hline$R_{m} * S^{G U A}$ & & & 0.442 & & & $0.494 * *$ \\
\hline Constant & $-0.00696^{* * *}$ & $-0.00700 * * *$ & $-0.00675^{* * *}$ & $-0.00710 * * *$ & $-0.00706^{* * *}$ & $-0.00702 * * *$ \\
\hline Bank\Time Dummies & Yes $\backslash$ Yes & Yes $\backslash$ Yes & Yes $\backslash$ Yes & Yes $\backslash$ Yes & Yes $\backslash$ Yes & Yes $\backslash$ Yes \\
\hline Observations & 37,835 & 37,835 & 37,835 & 37,835 & 37,835 & 37,835 \\
\hline Number of groups: banks & 115 & 115 & 115 & 115 & 115 & 115 \\
\hline Number of groups: days & 329 & 329 & 329 & 329 & 329 & 329 \\
\hline Adjusted $\mathrm{R}^{2}$ & 0.488 & 0.488 & 0.489 & 0.488 & 0.488 & 0.489 \\
\hline F Test & 95.14 & 176.0 & 75.16 & 108.9 & 82.70 & 69.75 \\
\hline Prob $>$ F & 0 & 0 & 0 & 0 & 0 & 0 \\
\hline Ann. Wald Test & 1.574 & 148.6 & 4.654 & 1.629 & 1.675 & 1.522 \\
\hline Ann. Wald Prob $>$ F & 0.178 & 0 & 0 & 0.164 & 0.123 & 0.154 \\
\hline LR Test & 3,889 & 3,889 & 3,678 & 3,898 & 3,896 & 3,628 \\
\hline LR Test Prob $>$ chi 2 & 0 & 0 & 0 & 0 & 0 & 0 \\
\hline $\begin{array}{l}\text { Notes: Data on } 18 \text { countries from } 15 / 09 / 2 \\
\text { days centred windows for general announ } \\
\text { error approach. Estimators: } L S D V=\text { Least } \\
\text { clustered standard errors; } C L_{t}=\text { day-clust } \\
\text { return; SIZEREL = capitalization value of } \\
\text { announcements; } A L L=\text { all types; } C A P=\end{array}$ & $\begin{array}{l}2008 \text { to } 31 / 12 / 2 \\
\text { incements and } \\
\text { st Squares Dum } \\
\text { tered standard } \\
\text { f bank } i \text { relativ } \\
=\text { capital injecti }\end{array}$ & $\begin{array}{l}\text { Shorter Even } \\
\text { days centre } \\
\text { ariables. Ban } \\
\text { Variables: } \\
\text { apitalization }\end{array}$ & $\begin{array}{l}\text { dows and } \\
\text { dows for } \\
\text { ne Effects } \\
\text { ank's rate } \\
\text { banks in }\end{array}$ & $\begin{array}{l}r \text { Event } W i \\
\text { c announce } \\
\text { bank dumm } \\
\text { urn (depen } \\
\text { mple; } G=\varepsilon\end{array}$ & $\begin{array}{l}\text { refers resp } \\
\text { Mixed }=\mathrm{c} \\
=\text { day dum } \\
\text { riable); } R_{m} \\
\text { announcen }\end{array}$ & $\begin{array}{l}\text { ly to } 5 \text { and } 9 \\
\text { y }+ \text { standard } \\
C L_{i}=\text { bank- } \\
\text { rket's rate of } \\
S=\text { specific } \\
\text { icance of the }\end{array}$ \\
\hline
\end{tabular}


Table 10 - Announcement impact on banks' rates of return: first and higher announcements

\begin{tabular}{|c|c|c|c|c|c|}
\hline $\begin{array}{r}\text { Approach } \\
\text { Model } \\
\text { Estimator } \\
\text { Bank/Time Effects } \\
\end{array}$ & $\begin{array}{l}\text { Parameter } \\
\text { Eq. (1) } \\
\text { OLS } \\
-- \\
(1)\end{array}$ & $\begin{array}{l}\text { Parameter } \\
\text { Eq. (1) } \\
\text { LSDV } \\
-- \\
(2)\end{array}$ & $\begin{array}{c}\mathrm{SE} \\
\text { Eq. (1) } \\
\text { FGLS } \\
\mathrm{XC}_{\mathrm{i}}+\mathrm{AR}(1) \\
\text { (3) }\end{array}$ & $\begin{array}{l}\text { Mixed } \\
\text { Eq. (1) } \\
\text { LSDV } \\
\text { DK }_{i+t} \\
(4)\end{array}$ & $\begin{array}{l}\text { Mixed } \\
\text { Eq. (1) } \\
\text { LSDV } \\
\mathrm{CL}_{\mathrm{i}+\mathrm{t}} \\
(5)\end{array}$ \\
\hline$R_{m}$ & $1.408 * * *$ & $1.314 * * *$ & $1.315^{* * *}$ & $1.314 * * *$ & $1.314 * * *$ \\
\hline SIZEREL & $0.0260 \#$ & $0.584 * * *$ & $0.0191 * *$ & $0.584 * * *$ & $0.584 * * *$ \\
\hline$G 1^{A L L}$ & $0.00325 * *$ & -0.00133 & 0.00130 & -0.00133 & -0.00133 \\
\hline$R_{m}^{*} G 1^{A L L}$ & $-0.118 * * *$ & $0.0767 * *$ & $-0.0868 * * *$ & 0.0767 & 0.0767 \\
\hline$S 1^{A L L}$ & $-0.00722 * * *$ & $-0.00507 * *$ & $-0.00298 * *$ & $-\mathbf{0 . 0 0 5 0 7 \# ~}$ & $-0.00507 \#$ \\
\hline$R_{m} * S 1^{A L L}$ & $0.116 *$ & $0.214 * * *$ & $0.128 * * *$ & $0.214 *$ & $0.214 * *$ \\
\hline$G 2^{A L L}$ & $0.00714 * * *$ & $0.00415 * * *$ & $0.00494 * * *$ & 0.00415 & 0.00415 \\
\hline$R_{m} * G 2^{A L L}$ & -0.0219 & $0.113 * * *$ & 0.0127 & 0.113 & 0.113 \\
\hline$S 2^{A L L}$ & -0.00324 & -0.00118 & -0.00204 & -0.00118 & -0.00118 \\
\hline$R_{m} * S 2^{A L L}$ & $0.446^{* * *}$ & $0.352 * * *$ & $0.362 * * *$ & 0.352 & 0.352 \\
\hline Constant & $-0.000406^{*}$ & $-0.00707 *$ & $-1.92 \mathrm{e}-05$ & $-0.00707 * * *$ & $-0.00707 * * *$ \\
\hline Bank $\backslash$ Time Dummies & NolNo & Yes $\backslash$ Yes & NolNo & Yes $\backslash$ Yes & Yes $\backslash$ Yes \\
\hline Observations & 37,835 & 37,835 & 37,835 & 37,835 & 37,835 \\
\hline Number of groups: banks & & 115 & 115 & 115 & 115 \\
\hline Number of groups: days & & 329 & 329 & 329 & 329 \\
\hline Adjusted $\mathrm{R}^{2}$ & 0.440 & 0.488 & 0.440 & 0.494 & 0.488 \\
\hline F Test & 2,975 & 1,254 & 30,333 & 59.56 & 69.74 \\
\hline Prob $>$ F & 0 & 0 & 0 & 0 & 0 \\
\hline Ann. Wald Test & 12.88 & 7.01 & 94.77 & 1.95 & 2.44 \\
\hline Ann. Wald Prob $>$ F & 0 & 0 & 0 & 0.0594 & 0.0124 \\
\hline Test $\alpha^{G}: G 1^{A L L}=G 2^{A L L}$ & 4.70 & 7.11 & 7.89 & 0.41 & 0.44 \\
\hline $\operatorname{Prob} \alpha^{G}>\mathrm{F}$ & 0.030 & 0.008 & 0.005 & 0.524 & 0.509 \\
\hline Test $\beta^{G}: R_{m} * G 1^{A L L}=R_{m} * G 2^{A L L}$ & 5.88 & 0.76 & 14.56 & 0.04 & 0.07 \\
\hline $\operatorname{Prob} \beta^{G}>\mathrm{F}$ & 0.015 & 0.384 & 0 & 0.840 & 0.793 \\
\hline Test $\alpha^{S}: S 1^{A L L}=S 2^{A L L}$ & 1.43 & 1.42 & 0.22 & 0.31 & 0.50 \\
\hline Prob $\alpha^{S}>\mathrm{F}$ & 0.232 & 0.233 & 0.634 & 0.577 & 0.450 \\
\hline Test $\beta^{S}: R_{m} * S 1^{A L L}=R_{m} * S 2^{A L L}$ & 6.91 & 1.29 & 6.52 & 0.08 & 0.05 \\
\hline $\operatorname{Prob} \beta^{S}>\mathrm{F}$ & 0.009 & 0.256 & 0.011 & 0.778 & 0.817 \\
\hline \multicolumn{6}{|c|}{$\begin{array}{l}\text { Notes: Data on } 18 \text { countries from 15/09/2008 to 31/12/2009. } S E=\text { standard errors; Mixed }=\text { dummy }+ \text { standard error approach. Estimators: } O L S \\
=\text { Ordinary Least Squares; } L S D V=\text { Least Squares Dummy Variables; } F G L S=\text { Feasible Generalized Least Squares. Bank/Time Effects: } A R(1)= \\
\text { one lag autoregressive standard errors. } X C_{i}=\text { cross-correlated standard errors; } D K_{i+t}=\text { Driscoll-Kraay standard errors; } C L_{i}=\text { bank-clustered } \\
\text { standard errors; } C L_{t}=\text { day-clustered standard errors. Variables: } R_{i}=\text { bank's rate of return (dependent variable); } R_{m}=\text { market's rate of return; } \\
S I Z E R E L=\text { capitalization value of bank } i \text { relative to capitalization of all banks in the sample; } G 1=\text { first general announcements (by country); } S I \\
=\text { first specific announcements (by banks); } A L L=\text { all types. Tests: F Test: joint statistical significance of the full specification; Ann. Wald: joint } \\
\text { statistical significance of announcements (bold variables); LR Test: Likelihood Ratio test of specification without dummies vs specification with } \\
\text { firm and/or time dummies; A-Corr. Test = Auto-Correlation Wooldridge test; X-Corr. Test = Cross-Correlation Wald Test. *** } \mathrm{p}<0.01 * * \\
\mathrm{p}<0.05 * \mathrm{p}<0.10 \# \mathrm{p}<0.15 \text {. }\end{array}$} \\
\hline
\end{tabular}


Table 11 - Parametric \& SE approach - Different Methods - First vs higher announcements

$\begin{array}{rccccc}\text { Approach } & \text { Parameter } & \text { Parameter } & \text { SE } & \text { Mixed } & \text { Mixed } \\ \text { Model } & \text { Eq. (3) } & \text { Eq. (3) } & \text { Eq. (3) } & \text { Eq. (3) } & \text { Eq. (3) } \\ \text { Estimator } & \text { OLS } & \text { LSDV } & \text { FGLS } & \text { LSDV } & \text { LSDV } \\ \text { me Effects } & -- & -- & \mathrm{XC}_{\mathrm{i}}+\mathrm{AR}(1) & \mathrm{DK}_{\mathrm{i}+\mathrm{t}} & \mathrm{CL}_{\mathrm{i}+\mathrm{t}}\end{array}$

\begin{tabular}{|c|c|c|c|c|c|}
\hline VARIABLE & (1) & (2) & (3) & (4) & (5) \\
\hline$R m$ & $1.412 * * *$ & $1.316^{* * *}$ & $1.316^{* * *}$ & $1.316^{* * *}$ & $1.316^{* * *}$ \\
\hline SIZEREL & $0.0293 *$ & $0.573 * * *$ & $0.0204 * * *$ & $0.573 * * *$ & $0.573 * * *$ \\
\hline$G 1^{C A P}$ & $0.00373 * *$ & -0.000643 & $0.00330 * * *$ & -0.000643 & -0.000643 \\
\hline$R_{m} * G 1$ & $0.189 * * *$ & $0.187 * * *$ & $0.126 * * *$ & $0.187 *$ & 0.187 \\
\hline$G 1^{G U A}$ & $0.00256 \#$ & 0.00162 & 0.000663 & 0.00162 & 0.00162 \\
\hline$R_{m} * G 1^{G U A}$ & $-0.530 * * *$ & $-0.258 * * *$ & $-0.354 * * *$ & $-0.258 *$ & $-0.258 * *$ \\
\hline$S 1^{\text {CAP }}$ & $-0.00782 * * *$ & $-0.00578 * *$ & $-0.00301 * *$ & $-0.00578 *$ & $-0.00578 \#$ \\
\hline$R_{m} * S 1^{C A P}$ & 0.0418 & 0.118* & $0.0771 *$ & 0.118 & 0.118 \\
\hline$S 1^{G U A}$ & -0.000367 & 0.00296 & -0.00276 & 0.00296 & 0.00296 \\
\hline$R_{m} * S 1^{G U A}$ & $0.306 * *$ & $0.419 * * *$ & $0.300 * * *$ & 0.419 & 0.419 \\
\hline$G 2^{C A P}$ & $0.00815 * * *$ & $0.00478 * * *$ & $0.00614 * * *$ & 0.00478 & 0.00478 \\
\hline$R_{m} * G 2^{C A P}$ & $0.322 * * *$ & $0.289 * * *$ & $0.215 * * *$ & 0.289 & $0.289 *$ \\
\hline$G 2^{G U A}$ & -0.00744 & $-0.00861 \#$ & $-0.00602 *$ & $-0.00861 \#$ & -0.00861 \\
\hline$R_{m} * G 2^{G U A}$ & $-0.730 * * *$ & $-0.443 * * *$ & $-0.485 * * *$ & $-0.443 *$ & $-0.443^{*}$ \\
\hline$S 2^{C A P}$ & $-0.00831 * * *$ & $-0.00649 * *$ & $-0.00315^{*}$ & -0.00649 & $-0.00649 *$ \\
\hline$R_{m} * S 2^{C A P}$ & $1.479 * * *$ & $1.269 * * *$ & $0.812 * * *$ & $1.269 * *$ & $1.269 * *$ \\
\hline$S 2^{G U A}$ & -0.00553 & -0.00449 & $-0.00656 \#$ & -0.00449 & -0.00449 \\
\hline$R_{m} * S 2^{G U A}$ & $0.350 * *$ & 0.240 & $0.440 * * *$ & 0.240 & 0.240 \\
\hline Constant & $-0.000440 *$ & $-0.00702 *$ & -0.000111 & $-0.00702 * * *$ & $-0.00702 * * *$ \\
\hline Bank\Time Dummies & No\No & Yes $\backslash$ Yes & No\No & Yes $\backslash Y$ es & Yes $\backslash$ Yes \\
\hline Observations & 37,835 & 37,835 & 37,835 & 37,835 & 37,835 \\
\hline Number of groups: banks & & 115 & 115 & 115 & 115 \\
\hline Number of groups: days & & 329 & 329 & 329 & 329 \\
\hline Adjusted R2 & 0.445 & 0.490 & 0.445 & 0.496 & 0.490 \\
\hline F Test & 1,686 & 705.8 & 29,395 & 41.43 & 71.92 \\
\hline Prob $>$ F & 0 & 0 & 0 & 0 & 0 \\
\hline Ann.WALD Test & 27.72 & 11.43 & 392.3 & 1.65 & 3.37 \\
\hline Ann.WALD Prob $>$ F & 0 & 0 & 0 & 0.0657 & 0 \\
\hline Test $\alpha^{G 1}: G 1^{C A P}=G 2^{C A P}$ & 5.36 & 6.23 & 3.35 & 0.28 & 0.37 \\
\hline $\operatorname{Prob} \alpha^{G l}>\mathrm{F}$ & 0.021 & 0.013 & 0.067 & 0.597 & 0.544 \\
\hline Test $\beta^{G I}: R_{m} * G 1^{C A P}=R_{m} * G 2^{C A P}$ & 9.72 & 5.05 & 6.17 & 0.27 & 0.43 \\
\hline $\operatorname{Prob} \beta^{G i}>\mathrm{F}$ & 0.002 & 0.025 & 0.013 & 0.602 & 0.512 \\
\hline Test $\alpha^{G 2}: G 1^{G U A}=G 2^{G U A}$ & 3.04 & 3.28 & 4.56 & 1.96 & 1.00 \\
\hline $\operatorname{Prob} \alpha^{G 2}>\mathrm{F}$ & 0.081 & 0.070 & 0.033 & 0.164 & 0.317 \\
\hline Test $\beta^{G 2}: R_{m} * G 1^{G U A}=R_{m} * G 2^{G U A}$ & 2.40 & 2.22 & 6.39 & 1.01 & 1.16 \\
\hline $\operatorname{Prob} \beta^{G 2}>\mathrm{F}$ & 0.121 & 0.137 & 0.011 & 0.317 & 0.281 \\
\hline Test $\alpha^{S 1}: S 1^{C A P}=S 2^{C A P}$ & 0.02 & 0.03 & 0 & 0.01 & 0.02 \\
\hline Prob $\alpha^{S l}>\mathrm{F}$ & 0.901 & 0.853 & 0.952 & 0.927 & 0.884 \\
\hline Test $\beta^{S I}: R_{m} * S 1^{C A P}=R_{m} * S 2^{C A P}$ & 60.14 & 40.99 & 34.46 & 3.43 & 4.06 \\
\hline $\operatorname{Prob} \beta^{S I}>\mathrm{F}$ & 0 & 0 & 0 & 0.067 & 0.044 \\
\hline Test $\alpha^{S 2}: S 1^{G U A}=S 2^{G U A}$ & 0.60 & 1.31 & 0.56 & 0.32 & 0.24 \\
\hline Prob $\alpha^{S 2}>\mathrm{F}$ & 0.440 & 0.252 & 0.454 & 0.570 & 0.623 \\
\hline Test $\beta^{S 2}: R_{m} * S 1^{G U A}=R_{m} * S 2^{G U A}$ & 0.04 & 0.74 & 0.58 & 0.13 & 0.13 \\
\hline $\operatorname{Prob} \beta^{S 2}>\mathrm{F}$ & 0.838 & 0.389 & 0.447 & 0.724 & 0.716 \\
\hline
\end{tabular}

Notes: Data on 18 countries from 15/09/2008 to 31/12/2009. $S E=$ standard errors; Mixed = dummy + standard error approach. Estimators: $O L S=$ Ordinary Least Squares; $L S D V=$ Least Squares Dummy Variables; $F G L S=$ Feasible Generalized Least Squares. Bank/Time Effects: $A R(1)=$ one lag autoregressive standard errors. $X C_{i}=$ cross-correlated standard errors; $D K_{i+t}=$ Driscoll-Kraay standard errors; $C L_{i}=$ bank-clustered standard errors; $C L_{t}=$ day-clustered standard errors. Variables: $R_{i}=$ bank's rate of return (dependent variable); $R_{m}=$ market's rate of return; SIZEREL $=$ capitalization value of bank $i$ relative to capitalization of all banks in the sample; $G 1=$ first general announcements (by country); $S I=$ first specific announcements (by banks); $C A P=$ capital injections; $G U A=$ asset and debt liabilities. Tests: F Test: joint statistical significance of the full specification; Ann. Wald: joint statistical significance of announcements (bold variables); LR Test: Likelihood Ratio test of specification without dummies vs specification with firm and/or time dummies; A-Corr. Test $=$ Auto-Correlation Wooldridge test; X-Corr. Test $=$ Cross-Correlation Wald Test. $* * * \mathrm{p}<0.01 * * \mathrm{p}<0.05 * \mathrm{p}<0.10 \# \mathrm{p}<0.15$. 
Table 12 - Alternative Definition of General and Specific Announcements

\begin{tabular}{|c|c|c|c|c|c|c|c|}
\hline Period & Crisis & Crisis & Crisis & Crisis & Turbulent Crisis & Crisis & Crisis \\
\hline Geography & World & World & World & World & World & USA & Europe \\
\hline Approach & Parameter & Parameter & SE & Mixed & Mixed & Parameter & Parameter \\
\hline Estimator & OLS & $\mathrm{LSDV}_{\mathrm{i}+\mathrm{t}}$ & FGLS & $\operatorname{LSDV}_{\mathrm{i}+\mathrm{t}}$ & $\operatorname{LSDV}_{\mathrm{i}+\mathrm{t}}$ & OLS & OLS \\
\hline SE Correction & -- & -- & $\mathrm{AR}(1)+\mathrm{XC}_{\mathrm{i}}$ & $\mathrm{CL}_{\mathrm{i}+\mathrm{t}}$ & $\mathrm{CL}_{\mathrm{i}+\mathrm{t}}$ & $\mathrm{DK}_{\mathrm{i}+\mathrm{t}}$ & $\mathrm{DK}_{\mathrm{i}+\mathrm{t}}$ \\
\hline Corresponding estimate & Tab.3 - Col.2 & Tab.3-Col.5 & Tab.4 - Col.5 & Tab.7-Col.2 & Tab. $8-$ Col. 1 & Tab.8 - Col.4 & Tab. $8-$ Col.7 \\
\hline VARIABLE & $(1)$ & $(2)$ & (3) & $(4)^{(a)}$ & $(5)$ & $(6)$ & (7) \\
\hline$R_{m}$ & $1.412 * * *$ & $1.315 * * *$ & $1.317 * * *$ & $1.315 * * *$ & $1.265 * * *$ & $1.813 * * *$ & $1.292 * * *$ \\
\hline SIZEREL & $0.0240 \#$ & $0.582 * * *$ & $0.0172 * *$ & $0.582 * * *$ & $1.477 * * *$ & 0.0433 & $0.0737 * *$ \\
\hline$G^{A L L}$ & $0.00463 * * *$ & $0.00104^{(--)}$ & $0.00291 * * *$ & 0.00104 & 0.00158 & $0.00750 \#^{(--)}$ & -0.00216 \\
\hline$R_{m} * G^{A L L}$ & $-0.0822 * * *$ & $0.0878 * * *$ & $-0.0474 * * * *^{(+++)}$ & 0.0878 & 0.0279 & -0.273 & $-0.220 * * *$ \\
\hline$S^{A L L}$ & $-0.00408 * *(-)$ & $-0.00230^{(-)}$ & $-0.00144^{(--)}$ & -0.00230 & $-0.00315^{(-)}$ & $-0.00645^{(-)}$ & -0.00187 \\
\hline$R_{m} * S^{A L L}$ & $0.337 * * *$ & $0.293 * * *$ & $0.274 * * *$ & $0.293 *$ & $0.400 *(-)$ & 0.0134 & $0.405 \#$ \\
\hline Constant & -0.000351 & $-0.00698^{*}$ & $2.45 \mathrm{e}-05$ & $-0.00698 * * *$ & $-0.0137 * * *$ & -0.000371 & -0.000383 \\
\hline Bank $\backslash$ Time Dummies & NolNo & Yes $\backslash$ Yes & No\No & Yes $\backslash$ Yes & Yes $\backslash$ Yes & NolNo & NolNo \\
\hline Observations & 37835 & 37835 & 37835 & 37835 & 13800 & 14476 & 14805 \\
\hline Number of groups: banks & -- & 115 & 115 & 115 & 115 & 44 & 45 \\
\hline Number of groups: days & -- & 329 & 329 & 329 & 120 & 329 & 329 \\
\hline Adjusted R2 & 0.440 & 0.488 & 0.440 & 0.488 & 0.504 & 0.456 & 0.434 \\
\hline F Test & 4953 & 2085 & 30261 & 97.29 & 71.73 & 54.50 & 214.6 \\
\hline Prob $>$ F & 0 & 0 & 0 & 0 & 0 & 0 & 0 \\
\hline Ann.WALD Test & 21.27 & 8.944 & 77.24 & 1.030 & 1.433 & 1.274 & 6.088 \\
\hline Ann. WALD Prob $>$ F & 0 & 0 & 0 & 0.390 & 0.220 & 0.295 & 0.000500 \\
\hline
\end{tabular}

Notes: Data on 18 countries from 15/09/2008 to 31/12/2009 except for Turbulent phase that goes from 15/09/2008 to 06/03/2009; Europe includes Austria, Belgium, Denmark, France, Germany, Greece, Ireland, Italy, Portugal, Netherlands, Norway, Spain, Sweden, Switzerland. $S E=$ standard errors; Mixed = dummy + standard error approach. Estimators: $O L S=$ Ordinary Least Squares; $L S D V=$ Least Squares Dummy Variables; FGLS

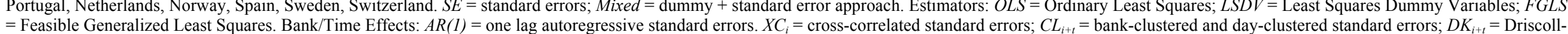
$=$ Feasible Generalized Least Squares. Bank/Time Effects: $A R(I)=$ one lag autoregressive standard errors. $X C_{i}=$ cross-correlated standard errors; $C L_{i+t}=$ bank-clustered and day-clustered standard errors; $D K_{i+t}=$ Driscoll-
Kraay standard errors. (a) $=$ same coefficients and significance levels using OLS with double clustered standard errors; $(-/--/--)=$ one/two/three significance level(s) less than the corresponding estimate; $(+/++/+++)=$ Kraay standard errors. (a) $=$ same coefficients and significance levels using OLS with double clustered standard errors; $(-/-/---)=$ one $/$ two/three significance level(s) less than the corresponding estimate; $(+/++/+++)=$
one/two/three significance level(s) more than the corresponding estimate. Variables: $R_{i}=$ bank's rate of return (dependent variable); $R_{m}=$ market's rate of return; SIZEREL $=$ capitalization value of bank $i$ relative to one/two/three significance level(s) more than the corresponding estimate. Variables: $R_{i}=$ bank's rate of return (dependent variable); $R_{m}=$ market's rate of return; SIZEREL $=$ capitalization value of bank $i$ relative to
capitalization of all banks in the sample; $G=$ general announcements; $S=$ specific announcements; $A L L=$ all type; specific announcements covering the period October 28,2008 through November 11,2008 have been aggregated as one general announcement with a 15-day event window: we apply consistently the two-trading day event windows of general announcements also to the implicit general announcement. Tests: F Test: joint statistical significance of the full specification; Ann. Wald: joint statistical significance of announcements (bold variables). ${ }^{* * *} \mathrm{p}<0.01 * * \mathrm{p}<0.05 * \mathrm{p}<0.10 \# \mathrm{p}<0.15$ 


\section{Appendix}

Table A1: List of banks included in market capitalization

\begin{tabular}{|c|c|c|c|}
\hline Area & Country & Bank Nr. & Bank Name \\
\hline \multirow{15}{*}{ Europe } & AT & 2 & ERSTE GROUP BANK AG, RAIFFEISEN INTL BANK HOLDING \\
\hline & $\mathrm{BE}$ & 2 & DEXIA SA, KBC GROEP NV \\
\hline & $\mathrm{CH}$ & 1 & VALIANT HOLDING AG-REG \\
\hline & $\mathrm{DE}$ & 3 & COMMERZBANK AG, DEUTSCHE POSTBANK AG, HYPO REAL ESTATE HOLDING \\
\hline & DK & 3 & DANSKE BANK A/S, JYSKE BANK-REG, SYDBANK A/S \\
\hline & ES & 6 & $\begin{array}{l}\text { BANCO BILBAO VIZCAYA ARGENTA, BANCO } \text { DE } \\
\text { POPULAR ESPANOL, BANCO SANTANDER SA, BANKINTER SA }\end{array}$ \\
\hline & FR & 4 & BNP PARIBAS, CREDIT AGRICOLE SA, NATIXIS, SOCIETE GENERALE \\
\hline & GR & 5 & $\begin{array}{l}\text { ALPHA BANK A.E., BANK OF GREECE, EFG EUROBANK ERGASIAS, NATIONAL } \\
\text { BANK OF GREECE, PIRAEUS BANK S.A. }\end{array}$ \\
\hline & IE & 1 & ALLIED IRISH BANKS PLC \\
\hline & IT & 8 & $\begin{array}{l}\text { BANCA CARIGE SPA, BANCA MONTE DEI PASCHI SIENA, BANCA POPOLARE DI } \\
\text { MILANO, BANCO POPOLARE SCARL, INTESA SANPAOLO, CREDITO } \\
\text { VALTELLINESE, UBI BANCA SCPA, UNICREDIT SPA }\end{array}$ \\
\hline & NL & 2 & ING GROEP, SNS REAAL \\
\hline & NO & 1 & DNB NOR ASA \\
\hline & PT & 3 & BANCO BPI SA, BANCO COMERCIAL PORTUGUES, BANCO ESPIRITO SANTO \\
\hline & $\mathrm{SE}$ & 4 & $\begin{array}{l}\text { NORDEA BANK AB, SKANDINAVISKA ENSKILDA, SVENSKA HANDELSBANKEN } \\
\text { SHS, SWEDBANK AB }\end{array}$ \\
\hline & UK & 6 & $\begin{array}{l}\text { BANK OF IRELAND, BARCLAYS PLC, HSBC HOLDINGS PLC, LLOYDS BANKING } \\
\text { GROUP PLC, ROYAL BANK OF SCOTLAND, STANDARD CHARTERED PLC }\end{array}$ \\
\hline \multirow{3}{*}{ Pacific } & AU & 6 & $\begin{array}{l}\text { AUST AND NZ BANKING GROUP, BANK OF QUEENSLAND LTD, BENDIGO AND } \\
\text { ADELAIDE BANK, COMMONWEALTH BANK OF AUSTRALIA, NATIONAL } \\
\text { AUSTRALIA BANK LTD, WESTPAC BANKING CORP }\end{array}$ \\
\hline & HK & 8 & $\begin{array}{l}\text { BANK OF CHINA LTD, BANK OF COMMUNICATIONS CO, BANK OF EAST ASIA, } \\
\text { BOC HONG KONG HOLDINGS LTD, CHINA CONSTRUCTION BANK, HANG SENG } \\
\text { BANK LTD, HSBC HOLDINGS PLC, IND \& COMM BANK OF CHINA }\end{array}$ \\
\hline & JP & 12 & $\begin{array}{l}\text { BANK OF YOKOHAMA LTD, CHIBA BANK LTD, CHUO MITSUI TRUST HOLDINGS, } \\
\text { FUKUOKA FINANCIAL GROUP INC., MITSUBISHI UFJ FINANCIAL GROUP, } \\
\text { MIZUHO FINANCIAL GROUP INC, MIZUHO TRUST \& BANKING CO, RESONA } \\
\text { HOLDINGS INC, SHINSEI BANK LTD, SHIZUOKA BANK LTD, SUMITOMO MITSUI } \\
\text { FINANCIAL GROUP, SUMITOMO TRUST \& BANKING CO }\end{array}$ \\
\hline USA & US & 45 & $\begin{array}{l}\text { AMERICAN CAPITAL LTD, AMERICAN EXPRESS CO, AMERIPRISE FINANCIAL } \\
\text { INC, BANK OF AMERICA CORP, BANK OF NEW YORK MELLON CORP, BB\&T } \\
\text { CORP, CAPITAL ONE FINANCIAL CORP, CIT GROUP INC, CITIGROUP INC, CMA } \\
\text { GROUP INC, COMERICA INC, DISCOVERY FINANCIAL SERVICES, E*TRADE } \\
\text { FINANCIAL CORP, FEDERATED INVESTORS INC, FIFTH THIRD BANCORP, FIRST } \\
\text { HORIZON NATIONAL CORP, FRANKLIN RESOURCES INC, GOLDMAN SACHS } \\
\text { GROUP INC, HUDSON CITY BANCORP INC, HUNTINGTON BANCSHARES INC, } \\
\text { INTERCONTINENTALEXCHANGE INC, INVESCO LTD, JANUS CAPITAL GROUP } \\
\text { INC, JPMORGAN CHASE \& CO, KEYCORP, LEGG MASON INC, LEUCADIA } \\
\text { NATIONAL CORP, M \& T BANK CORP, MARSHALL \& ILSLEY CORP, MOODY'S } \\
\text { CORP, MORGAN STANLEY, NASDAQ OMX GROUP, NORTHERN TRUST CORP, } \\
\text { NYSE EURONEXT, PEOPLE'S UNITED FINANCIAL, PNC FINANCIAL SERVICES } \\
\text { GROUP, REGIONS FINANCIAL CORP, SCHWAB (CHARLES) CORP, SLM CORP, } \\
\text { STATE STREET CORP, SUNTRUST BANKS INC, T ROWE PRICE GROUP INC, US } \\
\text { BANCORP, WELLS FARGO \& CO, ZIONS BANCORPORATION }\end{array}$ \\
\hline
\end{tabular}

NOTES: AT=Austria; $\mathrm{BE}=$ Belgium; $\mathrm{CH}=$ Switzerland; $\mathrm{DE}=$ Germany; $\mathrm{DK}=$ Denmark; EI=Eire; ES=Spain; $\mathrm{FR}=\mathrm{France}$; $\mathrm{GR}=$ Greece; $\mathrm{IT}=\mathrm{Italy} ; \mathrm{NO}=$ Norway; NL=Netherlands; $\mathrm{PT}=$ Portugal; $\mathrm{SE}=$ Sweden; UK=United Kingdom; AU=Australia; $\mathrm{HK}=$ Hong-Kong; JP=Japan; US=United States. 
Table A2: Timeline of general announcements (USD millions)

\begin{tabular}{|c|c|c|c|c|c|}
\hline \multirow[b]{2}{*}{ Data } & \multirow[b]{2}{*}{ Country } & \multicolumn{2}{|c|}{ Measure } & \multirow[b]{2}{*}{ Total } & \multirow[b]{2}{*}{ Cumulative } \\
\hline & & Capital Injections & $\begin{array}{l}\text { Asset and Debt } \\
\text { Guarantees }\end{array}$ & & \\
\hline $28 / 09 / 2008$ & $\mathrm{NL}$ & 29,192 & & 29,192 & 29,192 \\
\hline $30 / 09 / 2008$ & EI & 14,785 & 563,240 & 578,025 & 607,217 \\
\hline $02 / 10 / 2008$ & GR & 6,927 & & 6,927 & 614,144 \\
\hline $03 / 10 / 2008$ & US & 700,000 & & 700,000 & $1,314,144$ \\
\hline $05 / 10 / 2008$ & DK & - & & - & $1,314,144$ \\
\hline $07 / 10 / 2008$ & ES & 68,245 & 136,490 & 204,735 & $1,518,879$ \\
\hline \multirow[t]{2}{*}{$08 / 10 / 2008$} & IT & - & & - & \\
\hline & UK & 952,050 & 432,750 & $1,384,800$ & $2,903,679$ \\
\hline \multirow[t]{2}{*}{$09 / 10 / 2008$} & IT & & 1,362 & 1,362 & \\
\hline & NL & 27,292 & & 27,292 & $2,932,333$ \\
\hline $10 / 10 / 2008$ & ES & 40,413 & 134,710 & 175,123 & $3,107,456$ \\
\hline \multirow[t]{3}{*}{$12 / 10 / 2008$} & AT & 18,669 & 93,345 & 112,014 & \\
\hline & $\mathrm{AU}$ & & 5,225 & 5,225 & \\
\hline & PT & & 26,942 & 26,942 & $3,251,637$ \\
\hline \multirow[t]{2}{*}{$13 / 10 / 2008$} & $\mathrm{DE}$ & 107,768 & 538,840 & 646,608 & \\
\hline & US & 250,000 & & 250,000 & $4,148,245$ \\
\hline \multirow[t]{3}{*}{$14 / 10 / 2008$} & $\mathrm{HK}$ & - & & - & \\
\hline & NL & & 273,160 & 273,160 & \\
\hline & US & & $2,250,000$ & $2,250,000$ & $6,671,405$ \\
\hline \multirow[t]{3}{*}{$16 / 10 / 2008$} & $\mathrm{BE}$ & & - & - & \\
\hline & $\mathrm{CH}$ & 60,000 & & 60,000 & \\
\hline & FR & 53,664 & 429,312 & 482,976 & $7,214,381$ \\
\hline $23 / 10 / 2008$ & GR & & 29,619 & 29,619 & $7,244,000$ \\
\hline $24 / 10 / 2008$ & $\mathrm{NO}$ & 1,459 & 51,071 & 52,530 & $7,296,530$ \\
\hline $29 / 10 / 2008$ & SE & & 195,277 & 195,277 & $7,491,807$ \\
\hline $05 / 11 / 2008$ & $\mathrm{CH}$ & & - & - & $7,491,807$ \\
\hline $24 / 11 / 2008$ & PT & 5,156 & & 5,156 & $7,496,963$ \\
\hline $28 / 11 / 2008$ & IT & - & & - & $7,496,963$ \\
\hline $08 / 12 / 2008$ & FR & 27,825 & & 27,825 & $7,524,789$ \\
\hline $10 / 12 / 2008$ & $\mathrm{BE}$ & & - & - & $7,524,789$ \\
\hline $17 / 12 / 2008$ & JP & 136,612 & & 136,612 & $7,661,401$ \\
\hline $18 / 01 / 2009$ & DK & 17,770 & & 17,770 & $7,679,171$ \\
\hline $19 / 01 / 2009$ & UK & & 73,685 & 73,685 & $7,752,856$ \\
\hline $03 / 02 / 2009$ & $\mathrm{JP}$ & 11,225 & & 11,225 & $7,764,080$ \\
\hline \multirow[t]{2}{*}{$10 / 02 / 2009$} & SE & 7,928 & & 7,928 & \\
\hline & US & 100,000 & & 100,000 & $7,872,008$ \\
\hline $12 / 02 / 2009$ & EI & 8,975 & & 8,975 & $7,880,984$ \\
\hline $25 / 02 / 2009$ & IT & 15,277 & & 15,277 & $7,896,261$ \\
\hline $06 / 03 / 2009$ & $\mathrm{DE}$ & - & & - & $7,896,261$ \\
\hline $17 / 03 / 2009$ & JP & 10,116 & & 10,116 & $7,906,377$ \\
\hline $23 / 03 / 2009$ & US & 500,000 & & 500,000 & $8,406,377$ \\
\hline $13 / 05 / 2009$ & $\mathrm{DE}$ & & 272,240 & 272,240 & $8,678,617$ \\
\hline $22 / 07 / 2009$ & HK & & - & - & $8,678,617$ \\
\hline To & & $3,171,349$ & $5,507,268$ & $8,678,617$ & \\
\hline
\end{tabular}

NOTES: - = unspecified amount; $\mathrm{AT}=$ Austria; $\mathrm{BE}=\mathrm{Belgium}$; $\mathrm{CH}=$ Switzerland; $\mathrm{DE}=$ Germany; DK=Denmark; EI=Eire; ES=Spain; $\mathrm{FR}=$ France; $\mathrm{GR}=$ Greece; IT=Italy; $\mathrm{NO}=$ Norway; $\mathrm{NL}=$ Netherlands; $\mathrm{PT}=$ Portugal; $\mathrm{SE}=$ Sweden; $\mathrm{UK}=$ United Kingdom; $\mathrm{AU}=\mathrm{Australia}$; HK=Hong-Kong; JP=Japan; US=United States.

SOURCES: Mediobanca, BIS-BdI, DLA Piper, International Capital Market Association, and websites of national Ministries of Treasury or Finance. 
Table A3: Timeline of specific announcements (USD millions)

\begin{tabular}{|c|c|c|c|c|c|c|}
\hline \multirow[b]{2}{*}{ Data } & \multirow[b]{2}{*}{ Country } & \multirow[b]{2}{*}{ Bank } & \multicolumn{2}{|c|}{ Measure } & \multirow[b]{2}{*}{ Total } & \multirow[b]{2}{*}{ Cumulative } \\
\hline & & & $\begin{array}{c}\text { Capital } \\
\text { Injections }\end{array}$ & $\begin{array}{c}\text { Asset and Debt } \\
\text { Guarantees }\end{array}$ & & \\
\hline $14 / 03 / 2008$ & US & JP Morgan Chase \& Co & & 29,000 & 29,000 & 29,000 \\
\hline \multirow[t]{3}{*}{$30 / 09 / 2008$} & $\mathrm{BE}$ & Dexia & 4,224 & & 4,224 & \\
\hline & FR & Dexia & 4,224 & & 4,224 & \\
\hline & LU & Dexia & 529 & & 529 & 37,978 \\
\hline $06 / 10 / 2008$ & $\mathrm{DE}$ & Hypo Real Estate & & 67,540 & 67,540 & 105,518 \\
\hline \multirow[t]{3}{*}{$09 / 10 / 2008$} & $\mathrm{BE}$ & Dexia & & 123,837 & 123,837 & \\
\hline & FR & Dexia & & 74,712 & 74,712 & \\
\hline & $\mathrm{LU}$ & Dexia & & 6,141 & 6,141 & 310,208 \\
\hline \multirow[t]{2}{*}{$13 / 10 / 2008$} & UK & Lloyds TSB & 28,963 & & 28,963 & \\
\hline & & RBS & 34,074 & & 34,074 & 373,245 \\
\hline $19 / 10 / 2008$ & NL & ING Groep & 13,462 & & 13,462 & 386,707 \\
\hline $22 / 10 / 2008$ & SE & Swedbank AB & & 0 & 0 & 386,707 \\
\hline $27 / 10 / 2008$ & $\mathrm{BE}$ & KBC & 4,356 & & 4,356 & 391,063 \\
\hline \multirow[t]{8}{*}{$28 / 10 / 2008$} & US & Bank of America & 15,000 & & 15,000 & \\
\hline & & Bank of New York Mellon & 3,000 & & 3,000 & \\
\hline & & Citigroup & 25,000 & & 25,000 & \\
\hline & & Goldman Sachs Group & 10,000 & & 10,000 & \\
\hline & & JP Morgan Chase \& Co & 25,000 & & 25,000 & \\
\hline & & Morgan Stanley & 10,000 & & 10,000 & \\
\hline & & State Street Corp & 2,000 & & 2,000 & \\
\hline & & Wells Fargo Bank & 25,000 & & 25,000 & 506,063 \\
\hline $30 / 10 / 2008$ & $\mathrm{DE}$ & Hypo Real Estate & & 19,275 & 19,275 & 525,338 \\
\hline $03 / 11 / 2008$ & $\mathrm{DE}$ & Commerzbank & 6,321 & 19,079 & 25,400 & 550,738 \\
\hline $07 / 11 / 2008$ & US & Franklin Resources & 1,600 & & 1,600 & 552,338 \\
\hline $12 / 11 / 2008$ & NL & SNS Reaal & 942 & & 942 & 553,280 \\
\hline $13 / 11 / 2008$ & $\mathrm{DE}$ & Hypo Real Estate & & 25,052 & 25,052 & 578,332 \\
\hline \multirow[t]{11}{*}{$17 / 11 / 2008$} & US & BB\&T Corp & 3,134 & & 3,134 & \\
\hline & & Capital One Financial Corp & 3,555 & & 3,555 & \\
\hline & & Comerica & 2,250 & & 2,250 & \\
\hline & & First Horizon National Corp & 867 & & 867 & \\
\hline & & Huntington Bancshares & 1,398 & & 1,398 & \\
\hline & & Key Corp & 2,500 & & 2,500 & \\
\hline & & Northern Trust Corp & 1,576 & & 1,576 & \\
\hline & & Regions Financial Corp & 3,500 & & 3,500 & \\
\hline & & Sun Trust Banks & 3,500 & & 3,500 & \\
\hline & & US Bancorp & 6,599 & & 6,599 & \\
\hline & & Zions Bancorporation & 1,400 & & 1,400 & 608,610 \\
\hline $21 / 11 / 2008$ & $\mathrm{DE}$ & Hypo Real Estate & & 25,062 & 25,062 & 633,672 \\
\hline $23 / 11 / 2008$ & US & Citigroup & 20,000 & 262,000 & 282,000 & 915,672 \\
\hline $25 / 11 / 2008$ & PT & Banco Espirito Santo & & 1,955 & 1,955 & 917,627 \\
\hline $09 / 12 / 2008$ & $\mathrm{DE}$ & Hypo Real Estate & & 12,937 & 12,937 & 930,564 \\
\hline \multirow[t]{3}{*}{$11 / 12 / 2008$} & FR & BNP Paribas & 3,390 & & 3,390 & \\
\hline & & Crédit Agricole & 3,988 & & 3,988 & \\
\hline & & Societé Générale & 2,260 & & 2,260 & 940,202 \\
\hline \multirow[t]{2}{*}{$21 / 12 / 2008$} & EI & Allied Irish Banks & 2,775 & & 2,775 & \\
\hline & & Bank of Ireland Group & 2,775 & & 2,775 & 945,752 \\
\hline $23 / 12 / 2008$ & US & M\&T Bank Corp & 600 & & 600 & 946,352 \\
\hline
\end{tabular}




\begin{tabular}{|c|c|c|c|c|c|}
\hline \multirow[t]{6}{*}{$31 / 12 / 2008$} & $\mathrm{DE}$ & Commerzbank & 13,919 & 13,919 & \multirow[b]{6}{*}{994,938} \\
\hline & \multirow[t]{5}{*}{ US } & CIT Group & 2,330 & 2,330 & \\
\hline & & Citigroup & 20,000 & 20,000 & \\
\hline & & Fifth Third Bancorp & 3,408 & 3,408 & \\
\hline & & PNC Financial Services Group & 7,579 & 7,579 & \\
\hline & & Sun Trust Banks & 1,350 & 1,350 & \\
\hline $08 / 01 / 2009$ & DE & Commerzbank & 6,857 & 6,857 & $1,001,795$ \\
\hline \multirow[t]{2}{*}{ 09/01/2009 } & \multirow[t]{2}{*}{ US } & American Express Company & 3,389 & 3,389 & \\
\hline & & Bank of America & 10,000 & 10,000 & $1,015,184$ \\
\hline \multirow[t]{2}{*}{$12 / 01 / 2009$} & \multirow[t]{2}{*}{ GR } & Alpha Bank AE & 1,268 & 1,268 & \\
\hline & & EFG Eurobank Ergasias & 1,268 & 1,268 & $1,017,720$ \\
\hline $14 / 01 / 2009$ & AT & Erste Group Bank & 7,904 & 7,904 & $1,025,624$ \\
\hline \multirow[t]{2}{*}{$16 / 01 / 2009$} & \multirow[t]{2}{*}{ US } & Bank of America & 97,000 & 117,000 & \\
\hline & & Citigroup & 7,000 & 7,000 & $1,149,624$ \\
\hline $19 / 01 / 2009$ & NL & SNS Reaal & 2,649 & 2,649 & $1,152,273$ \\
\hline $20 / 01 / 2009$ & $\mathrm{DE}$ & Hypo Real Estate & 15,535 & 15,535 & $1,167,808$ \\
\hline \multirow[t]{2}{*}{$22 / 01 / 2009$} & $\mathrm{BE}$ & $\mathrm{KBC}$ & 2,591 & 2,591 & \\
\hline & GR & National Bank of Greece & 453 & 453 & $1,170,853$ \\
\hline $23 / 01 / 2009$ & GR & Pireus Bank & 475 & 475 & $1,171,328$ \\
\hline $26 / 01 / 2009$ & NL & ING Groep & 28,346 & 28,346 & $1,199,674$ \\
\hline $30 / 01 / 2009$ & NL & ING Groep & 14,597 & 14,597 & $1,214,270$ \\
\hline $05 / 02 / 2009$ & $\mathrm{AT}$ & Raiffeisen Zentralbank Osterreich AG & 1,926 & 1,926 & $1,216,196$ \\
\hline $10 / 02 / 2009$ & $\mathrm{DE}$ & Hypo Real Estate & 12,966 & 12,966 & $1,229,162$ \\
\hline \multirow[t]{2}{*}{$12 / 02 / 2009$} & \multirow[t]{2}{*}{ EI } & Allied Irish Banks & 1,923 & 1,923 & \\
\hline & & Bank of Ireland Group & 1,923 & 1,923 & $1,233,009$ \\
\hline $20 / 02 / 2009$ & NL & ING Groep & 4,000 & 4,000 & $1,237,009$ \\
\hline $26 / 02 / 2009$ & UK & RBS & 466,115 & 484,760 & $1,721,768$ \\
\hline $27 / 02 / 2009$ & $\mathrm{AT}$ & Erste Group Bank & 3,419 & 3,419 & $1,725,187$ \\
\hline $05 / 03 / 2009$ & NL & SNS Reaal & 2,513 & 2,513 & $1,727,700$ \\
\hline $07 / 03 / 2009$ & $\mathrm{UK}$ & Lloyds TSB & 366,860 & 366,860 & $2,094,560$ \\
\hline $10 / 03 / 2009$ & IT & Banco Popolare & 1,849 & 1,849 & $2,096,409$ \\
\hline $12 / 03 / 2009$ & NL & ING Groep & 2,000 & 2,000 & $2,098,409$ \\
\hline \multirow[t]{4}{*}{$13 / 03 / 2009$} & AT & Raiffeisen Zentralbank Osterreich AG & 1,611 & 1,611 & \\
\hline & $\mathrm{BE}$ & Dexia & 15,082 & 15,082 & \\
\hline & \multirow[t]{2}{*}{ US } & Discover Financial Services & 1,225 & 1,225 & \\
\hline & & Morgan Stanley & 1,225 & 1,225 & $2,117,552$ \\
\hline $18 / 03 / 2009$ & IT & Unicredit Group & 2,622 & 2,622 & $2,120,174$ \\
\hline $20 / 03 / 2009$ & IT & Intesa Sanpaolo & 5,426 & 5,426 & $2,125,600$ \\
\hline $24 / 03 / 2009$ & IT & Banca Popolare di Milano & 676 & 676 & $2,126,277$ \\
\hline $27 / 03 / 2009$ & IT & Banca Monte dei Paschi di Siena & 2,528 & 2,528 & $2,128,805$ \\
\hline $28 / 03 / 2009$ & $\mathrm{DE}$ & Hypo Real Estate & 79,703 & 79,703 & $2,208,508$ \\
\hline $31 / 03 / 2009$ & FR & BNP Paribas & 6,763 & 6,763 & $2,215,271$ \\
\hline 04/04/2009 & US & Bank of America & 799 & 799 & $2,216,070$ \\
\hline \multirow[t]{3}{*}{$13 / 04 / 2009$} & \multirow[t]{3}{*}{ US } & Citigroup & 2,071 & 2,071 & \\
\hline & & JP Morgan Chase \& Co & 2,700 & 2,700 & \\
\hline & & Wells Fargo Bank & 2,873 & 2,873 & $2,223,713$ \\
\hline $15 / 04 / 2009$ & NL & SNS Reaal & 369 & 369 & $2,224,082$ \\
\hline $17 / 04 / 2009$ & DE & Hypo Real Estate & 162 & 162 & $2,224,244$ \\
\hline $21 / 04 / 2009$ & NL & SNS Reaal & 908 & 908 & $2,225,153$ \\
\hline $22 / 04 / 2009$ & NL & SNS Reaal & 729 & 729 & $2,225,881$ \\
\hline $04 / 05 / 2009$ & $\mathrm{AT}$ & Raiffeisen Zentralbank Osterreich AG & 2,005 & 2,005 & $2,227,886$ \\
\hline $07 / 05 / 2009$ & $\mathrm{DE}$ & Commerzbank & 10,997 & 10,997 & $2,238,883$ \\
\hline
\end{tabular}




\begin{tabular}{|c|c|c|c|c|c|}
\hline $13 / 05 / 2009$ & $\mathrm{BE}$ & $\mathrm{KBC}$ & 2,042 & 2,042 & $2,240,925$ \\
\hline $14 / 05 / 2009$ & $\mathrm{BE}$ & $\mathrm{KBC}$ & 27,216 & 27,216 & $2,268,141$ \\
\hline $22 / 05 / 2009$ & US & Franklin Resources & 5 & 5 & $2,268,146$ \\
\hline $28 / 05 / 2009$ & FR & Societé Générale & 2,371 & 2,371 & $2,270,517$ \\
\hline $02 / 06 / 2009$ & $\mathrm{DE}$ & Hypo Real Estate & 4,224 & 4,224 & $2,274,741$ \\
\hline $12 / 06 / 2009$ & US & Citigroup & 1,010 & 1,010 & $2,275,751$ \\
\hline $16 / 06 / 2009$ & US & Bank of America & 6 & 6 & $2,275,757$ \\
\hline $19 / 06 / 2009$ & IT & Banco Popolare & 0 & 0 & $2,275,757$ \\
\hline 08/07/2009 & US & State Street Corp & 60 & 60 & $2,275,817$ \\
\hline $15 / 07 / 2009$ & US & US Bancorp & 139 & 139 & $2,275,956$ \\
\hline $17 / 07 / 2009$ & US & PNC Financial Services Group & 54 & 54 & $2,276,010$ \\
\hline \multirow[t]{2}{*}{$22 / 07 / 2009$} & US & BB\&T Corp & 67 & 67 & \\
\hline & & Goldman Sachs Group & 1,100 & 1,100 & $2,277,177$ \\
\hline $29 / 07 / 2009$ & US & American Express Company & 340 & 340 & $2,277,517$ \\
\hline $05 / 08 / 2009$ & US & Bank of New York Mellon & 136 & 136 & $2,277,653$ \\
\hline $12 / 08 / 2009$ & US & Morgan Stanley & 950 & 950 & $2,278,603$ \\
\hline $26 / 08 / 2009$ & US & Northern Trust Corp & 87 & 87 & $2,278,690$ \\
\hline $21 / 09 / 2009$ & IT & Banca Popolare di Milano & 0 & 0 & $2,278,690$ \\
\hline \multirow[t]{3}{*}{$30 / 09 / 2009$} & US & Bank of America & 163 & 163 & \\
\hline & & Invesco Legacy Securities Master Fund & 3,330 & 3,330 & \\
\hline & & Wells Fargo Bank & 65 & 65 & $2,282,248$ \\
\hline $05 / 10 / 2009$ & $\mathrm{DE}$ & Hypo Real Estate & 232 & 232 & $2,282,480$ \\
\hline \multirow[t]{2}{*}{$03 / 11 / 2009$} & UK & Lloyds TSB & 12,287 & 12,287 & \\
\hline & & RBS & 9,830 & 9,830 & $2,304,597$ \\
\hline $04 / 11 / 2009$ & $\mathrm{DE}$ & Hypo Real Estate & 4,451 & 4,451 & $2,309,048$ \\
\hline $03 / 12 / 2009$ & US & Capital One Financial Corp & 149 & 149 & $2,309,196$ \\
\hline $10 / 12 / 2009$ & US & JP Morgan Chase \& Co & 950 & 950 & $2,310,147$ \\
\hline $14 / 12 / 2009$ & IT & Banca Monte dei Paschi di Siena & 0 & 0 & $2,310,147$ \\
\hline $21 / 12 / 2009$ & $\mathrm{DE}$ & Hypo Real Estate & 61,572 & 61,572 & $2,371,718$ \\
\hline \multirow[t]{4}{*}{$30 / 12 / 2009$} & IT & Credito Valtellinese & 286 & 286 & \\
\hline & US & Bank of America & 666 & 666 & \\
\hline & & PNC Financial Services Group & 19 & 19 & \\
\hline & & Wells Fargo Bank & 1,213 & 1,213 & $2,373,903$ \\
\hline $11 / 01 / 2010$ & EI & Bank of Ireland Group & 18,751 & 18,751 & $2,392,654$ \\
\hline $13 / 01 / 2010$ & EI & Bank of Ireland Group & 5,797 & 5,797 & $2,398,451$ \\
\hline $21 / 01 / 2010$ & EI & Allied Irish Banks & 17,068 & 17,068 & $2,415,519$ \\
\hline Total & & & $1,451,760$ & $2,415,519$ & \\
\hline
\end{tabular}

